Review

\title{
Positron Emission Tomography Reporter Genes and Reporter Probes: Gene and Cell Therapy Applications
}

\author{
Shahriar S. Yaghoubi1 ${ }^{1,2}$, Dean O. Campbell ${ }^{1}$, Caius G. Radu ${ }^{1}$ and Johannes Czernin ${ }^{1}$ \\ 1. UCLA School of Medicine, Department of Molecular and Medical Pharmacology \\ 2. Cellsight Technologies, Inc.
}

$\checkmark$ Corresponding author: Shahriar S. Yaghoubi, E-mails: syaghoubi@mednet.ucla.edu; syaghoubi@cellsighttech.com.

( ) Ivyspring International Publisher. This is an open-access article distributed under the terms of the Creative Commons License (http://creativecommons.org/ licenses/by-nc-nd/3.0/). Reproduction is permitted for personal, noncommercial use, provided that the article is in whole, unmodified, and properly cited.

Received: 2011.10.19; Accepted: 2012.02.09; Published: 2012.04.10

\begin{abstract}
Positron emission tomography (PET) imaging reporter genes (IRGs) and PET reporter probes (PRPs) are amongst the most valuable tools for gene and cell therapy. PET IRGs/PRPs can be used to non-invasively monitor all aspects of the kinetics of therapeutic transgenes and cells in all types of living mammals. This technology is generalizable and can allow long-term kinetics monitoring. In gene therapy, PET IRGs/PRPs can be used for whole-body imaging of therapeutic transgene expression, monitoring variations in the magnitude of transgene expression over time. In cell or cellular gene therapy, PET IRGs/PRPs can be used for whole-body monitoring of therapeutic cell locations, quantity at all locations, survival and proliferation over time and also possibly changes in characteristics or function over time. In this review, we have classified PET IRGs/PRPs into two groups based on the source from which they were derived: human or non-human. This classification addresses the important concern of potential immunogenicity in humans, which is important for expansion of PET IRG imaging in clinical trials. We have then discussed the application of this technology in gene/cell therapy and described its use in these fields, including a summary of using PET IRGs/PRPs in gene and cell therapy clinical trials. This review concludes with a discussion of the future direction of PET IRGs/PRPs and recommends cell and gene therapists collaborate with molecular imaging experts early in their investigations to choose a PET IRG/PRP system suitable for progression into clinical trials.
\end{abstract}

Key words: Positron Emission Tomography, PET Imaging Reporter Genes, Therapeutic Transgenes, Genetically Modified Therapeutic Cells, Imaging Therapeutic Transgenes or Cells

\section{Introduction}

The fields of gene and cellular gene therapy have seen considerable progress over the past two decades with both viral and non-viral transgene delivery techniques advancing into clinical trials. ${ }^{1-3}$ Yet, there is only one gene therapy drug, Gendicine (Shenzhen SiBiono Gene Technologies Co. (SiBiono) Ltd.) approved for commercialization in China. Concerns about safety (mutagenesis, immune reactions, etc...) and limited demonstrations of efficacy are slowing the advancement of gene therapeutics into approved drugs. Monitoring the kinetics of administered therapeutic transgenes, especially during clinical trials would help in the optimization of both gene therapeutic agents and their administration protocols.

In gene therapy we monitor kinetics by determining the sites, magnitude and time variation of therapeutic transgene expression in vivo following administration. In cellular gene therapy kinetics are 
monitored by tracking the locations of genetically engineered therapeutic cells, measuring their quantity at each location and determining changes in their characteristics at various time points in vivo following their administration. These kinetic studies will also provide information about proliferation and persistence of genetically engineered therapeutic cells. Ideally, kinetic studies should be non-invasive, to avoid potential complications of surgical procedures or tissue sampling. In addition, whole-body kinetics monitoring would be ideal.

Molecular imaging reporter genes (IRGs) offer a generalizable method for non-invasive, whole-body therapeutic transgene/cell kinetics monitoring in vivo.4-10 Although IRGs are available for fluorescence, bioluminescence and magnetic resonance imaging, radionuclide based IRGs are currently the only reporter genes for non-invasive imaging of transgene expression in humans. $7,11-17$

Positron emission tomography (PET) takes advantage of coincidence detection of two $511 \mathrm{KeV}$ gamma rays, emitted at an angle of about $180^{\circ}$ when positrons collide with electrons (Figure 1). This annihilation event allows precise detection of the location of positron radiolabeled molecules and uniquely permits the quantification of molecular events in vivo. Furthermore, the short half-life of fluorine-18, the radioisotope that is commonly used for labeling PET tracers allows for repetitive imaging, which in turn permits studying kinetics in vivo. In this review, we will focus on PET IRGs and their applications in gene and cellular gene therapies.

PET imaging probes reveal the presence of their target by accumulating on the surface or inside the cells containing the target while clearing from other cells. PET reporter probes (PRPs) image the expression of their PET IRGs in the same manner, by accumulating on the surface or inside the cells expressing the PET IRGs. Therefore, traditionally, PET IRG/PRP systems have been classified into three groups based on the way the protein product of the PET IRG interacts with its PRP to cause its accumulation: (i) PET IRGs encoding enzymes that phosphorylate specific PRPs which causes their intracellular entrapment (Figure 2A); (ii) PET IRGs encoding protein receptors that can be bound by specific PRPs (Figure 2B); (iii) PET IRGs encoding cell membrane transporters that facilitate the flow and accumulation of specific PRPs into cells (Figure 2C).

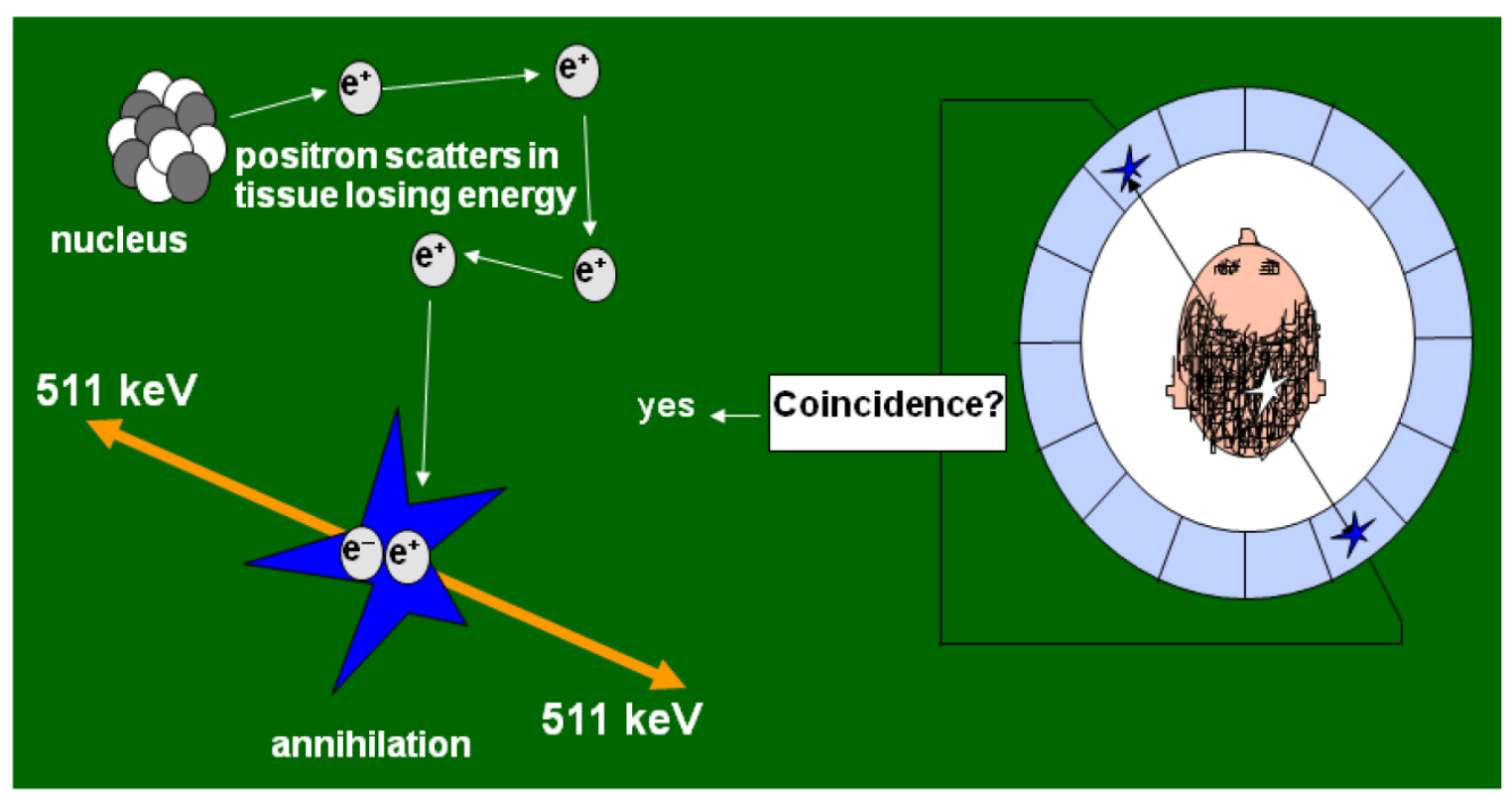

Fig. I. Mechanism of positron emission tomography (PET) imaging. PET is a molecular imaging modality useful for pre-clinical and clinical imaging of molecular events in living subjects. PET imaging involves a positron emitting radioisotope labeled imaging probe and instrumentation that can detect in a coincidence manner the radiation emitted when positrons from the imaging probe collide with nearby electrons. In this manner, PET cameras acquire data about the precise location of imaging probes inside the body of a living subject and the amount of imaging probe accumulated at every site at any given time. PET imaging probes usually accumulate at a site through binding to receptor molecules, interaction with an enzyme, or a cellular transport mechanism. 
A:

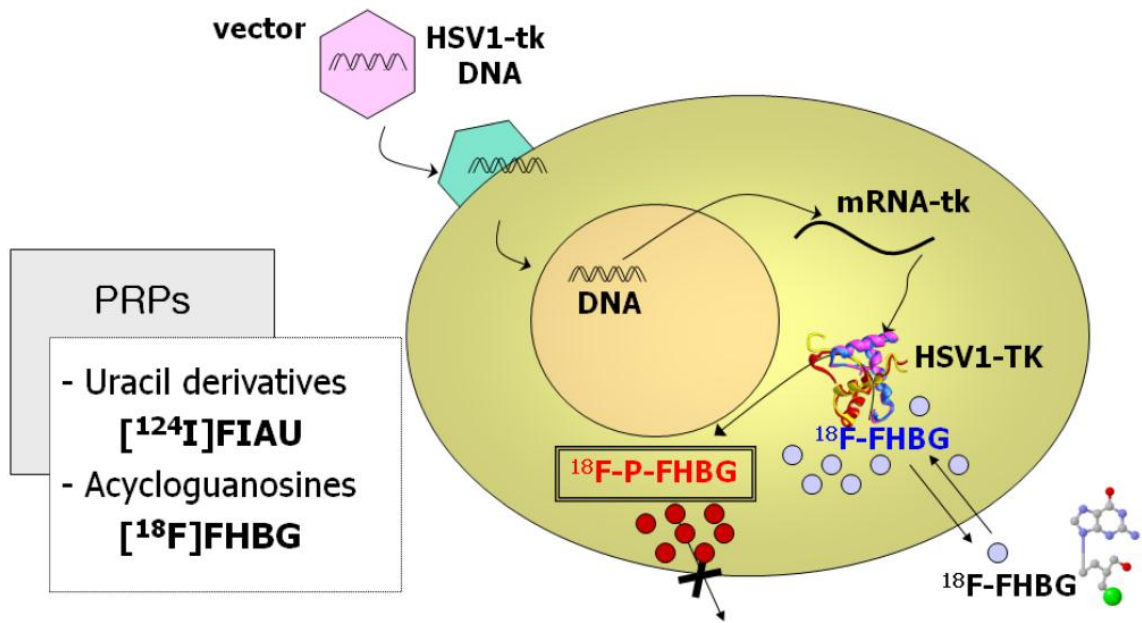

B:

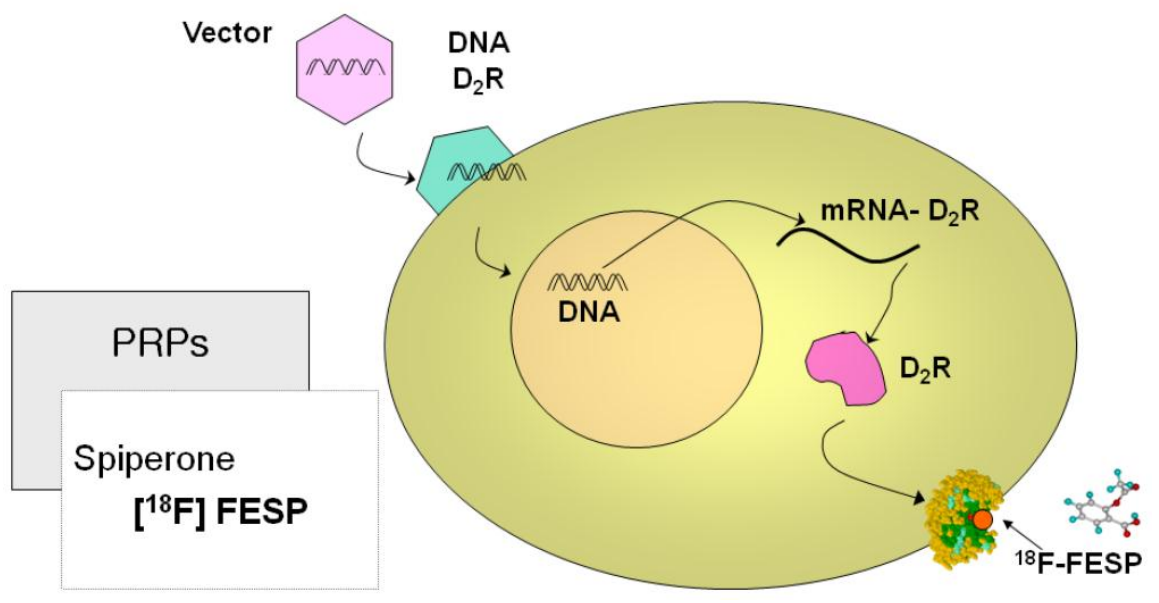

C:

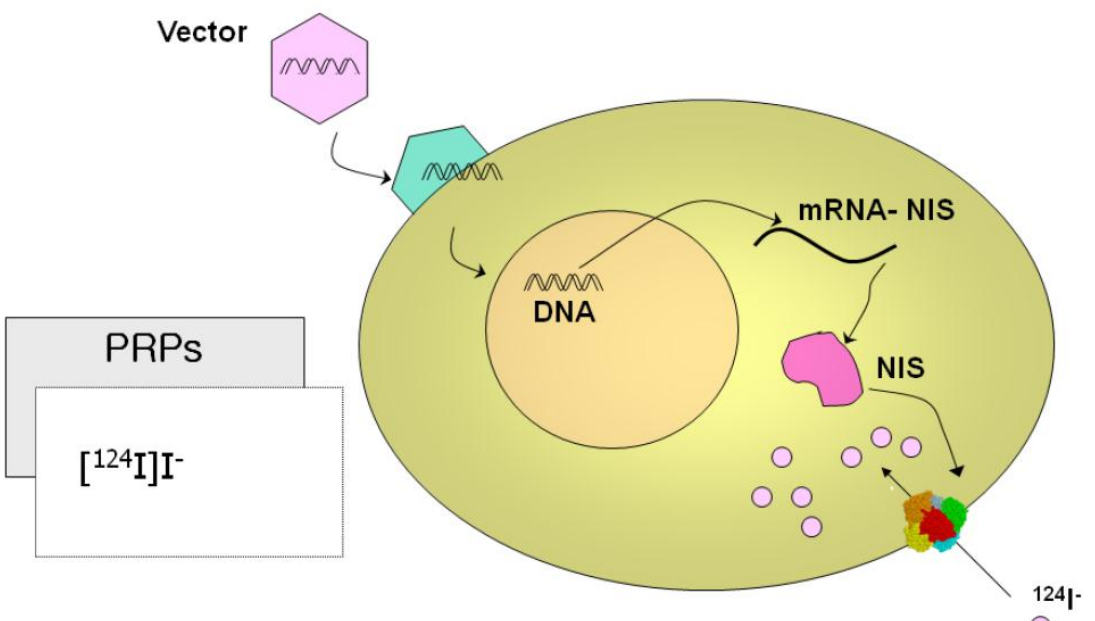

○

Fig. 2. Traditional classification of PET IRG/PRP systems based on their mechanism of action. A) The reporter gene encodes an enzyme that catalyzes chemical transformation of the reporter probe, thereby the reporter probes gets trapped within cells expressing the reporter gene. B) The reporter gene encodes a protein receptor that can be specifically bound by a radiolabeled ligand reporter probe. C) The reporter gene encodes a protein transporter that transports the radionuclide reporter probe into the cells expressing the reporter gene. Illustrations reprinted from review article by Penuelas et al. ${ }^{12}$ 
An unresolved issue of using IRGs to monitor therapeutic transgene or cell kinetics is immunogenicity of IRGs. As illustrated in figure 3, immunogenicity of a PET IRG can be detrimental to adoptively transferred therapeutic cells expressing it. Therefore, most recently, efforts towards developing human derived PET IRGs are being intensified. Current PET IRG and PRP systems can be grouped into a) those derived from viruses and other non-human sources that are likely to be rejected by the human immune system, and b) human gene-based PET IRGs that are less likely to be rejected by the human immune system. Table 1 suggests characteristics of a PET reporter gene/probe system that would be best suited for clinical gene and cell therapy applications. Table 2 lists the PET IRG/PRP systems that have thus far been studied.

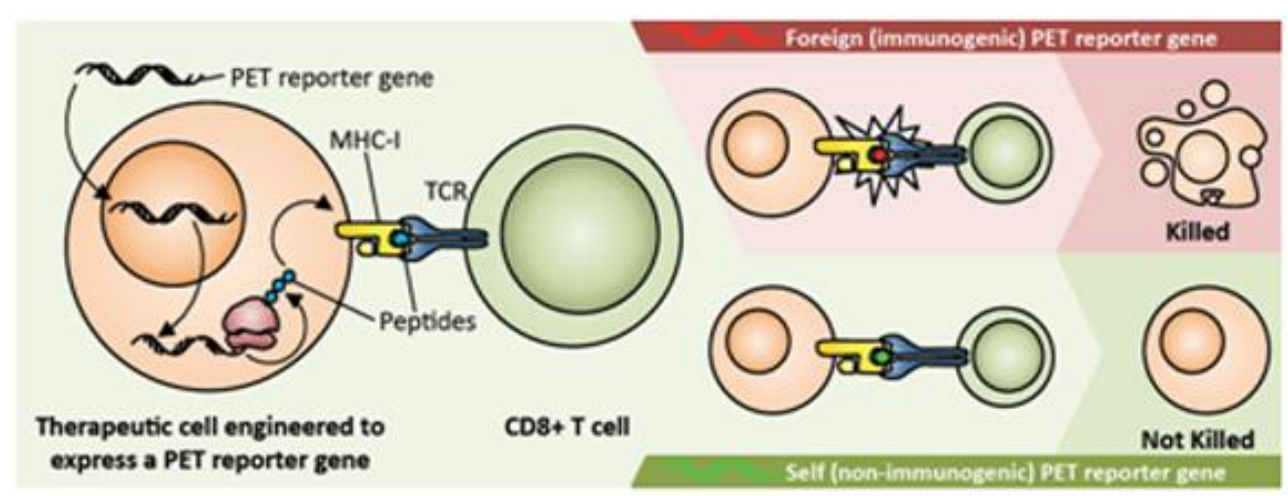

Fig. 3. The mechanism and consequences of PRG immunogenicity. The PRG is transcribed and translated in genetically engineered therapeutic cells; peptides derived from the PRG are displayed on the cell surface in the context of MHC class I molecules. If these peptides have never been encountered by the host immune system (i.e., they are 'foreign'), they are detected by CD8+ T cells, which then kill the therapeutic cells, leading to treatment failure. In contrast, if the PRG is sufficiently similar or identical to a gene normally expressed by the host ('self' rather than 'foreign') it is less likely that the therapeutic cells will be detected as 'foreign' and eliminated.

Table I: Characteristics of an ideal PET reporter gene (PRG)/probe (PRP) system for clinical gene and cell therapy imaging applications.

1. The protein encoded by the PRG does not cause an immune reaction. Ideally the PRG is a human-derived gene that is not expressed.

2. The protein encoded by the PRG is inert. It does not cause cytotoxicity by itself and after interaction with the trace amounts of the PRP. It also does not alter the normal or intended functions of the cells, having no effect on the cells' characteristics.

3. Image signal correlates well with the levels of PRG mRNA and protein in tissues of the living subject.

4. For transgene delivery applications, the size of the PRG is small enough to fit into the appropriate transgene delivery vehicle.

5. For cell therapy applications, the PRG can also serve as a safety gene, enabling suicide elimination of therapeutic cells if they are causing severe adverse effects.

6. PRP can be synthesized rapidly enough before significant decay has occurred and with high specific activity.

7. The PRP is accumulated only by the cells expressing the PRG. The PRP is cleared rapidly from organs or tissues that do not contain the cells expressing the PRG. The PRP does not attach to and rapidly effluxes from cells not expressing the PRG.

8. The PRP is stable and the signal emitting moiety of the PRP is not cleaved before reaching target cells and while accumulated by the PRG expressing cells. Excess PRP is cleared or metabolized and cleared rapidly to reduce background.

9. PRP or its metabolites are not toxic at 100X the required administered doses. This is unlikely to be an issue for PET tracers.

10. The PRP has ideal dosimetry in humans, allowing injection of sufficient doses, multiple times within a year without exceeding 5 REM to any organ or 3 REM to sensitive organs, such as bone marrow, lens of the eyes, testicles and ovaries.

11. PRP can cross physiological barriers to reach the target PRG expressing cells. For example, an ideal PRP would cross the blood brain barrier. 
Table 2: PET reporter gene/probe systems

\begin{tabular}{|c|c|c|c|}
\hline Reporter Gene & Reporter Probe & Advantages & Disadvantages \\
\hline \multicolumn{4}{|c|}{ 1. Reporter Genes Potentially Immunogenic in Humans } \\
\hline $\begin{array}{l}\text { Herpes Simplex Virus thy- } \\
\text { midine kinase } \\
\text { (HSV1-tk) and mutants: } \\
\text { HSV1-sr39tk, } \\
\text { HSV1-A167Ysr39tk, } \\
\text { HSV1-A167Ytk, } \\
\text { HSV1-A168Htk, } \\
\text { HSV1-R176Qtk, Destabi- } \\
\text { lized HSV1-tk }\end{array}$ & $\begin{array}{l}{\left[{ }^{18} \mathrm{~F}\right] \mathrm{FHBG}} \\
{\left[{ }^{18} \mathrm{~F}\right] \mathrm{FEAU}} \\
{\left[{ }^{124} \mathrm{I}\right] \mathrm{FIAU}}\end{array}$ & $\begin{array}{l}\text { 1. Relatively high sensitivity } \\
\text { 2. Most validated PET reporter } \\
\text { gene/probe system } \\
\text { 3. Absence of reporter gene in normal } \\
\text { mammalian cells } \\
\text { 4. Several PRPs with good pharmaco- } \\
\text { kinetics } \\
\text { 5. FDA IND approved PRP } \\
\text { ([18F]FHBG) } \\
\text { 6. Dual purpose IRG and suicide gene }\end{array}$ & $\begin{array}{l}\text { 1. Available probes don't cross the BBB } \\
\text { 2. High activity in organs involved in } \\
\text { clearance } \\
\text { 3. Deiodination of the radio-iodine la- } \\
\text { beled probes } \\
\text { 4. Possible perturbation of cell character- } \\
\text { istics like all other reporter genes }\end{array}$ \\
\hline $\begin{array}{l}\text { Varicella-Zoster Virus } \\
\text { Thymidine Kinase (VZV-tk) }\end{array}$ & {$\left[{ }^{18} \mathrm{~F}\right.$ or $\left.{ }^{11} \mathrm{C}\right] \mathrm{BCNA}$} & $\begin{array}{l}\text { Probes specific for VZV-tk and not } \\
\text { HSV1-tk }\end{array}$ & BCNA did not cross BBB \\
\hline LacZ & $\begin{array}{l}{\left[{ }^{11} \mathrm{C}\right] \beta \text {-galactosyl }} \\
\text { triazoles }\end{array}$ & & Probes not specific for LacZ \\
\hline \multicolumn{4}{|c|}{ 2. Reporter Genes Less Likely to be Immunogenic in Humans } \\
\hline $\begin{array}{l}\text { Modified human mito- } \\
\text { chondrial thymidine kinase } \\
\text { (hmTK2) and optimized } \\
\text { mutants }\end{array}$ & $\begin{array}{l}{\left[{ }^{18} \mathrm{~F}\right] \mathrm{FEAU}} \\
{\left[{ }^{124} \mathrm{I}\right] \mathrm{FIAU},\left[{ }^{18} \mathrm{~F}\right] \mathrm{L}-\mathrm{FMAU}}\end{array}$ & $\begin{array}{l}\text { 1. Dual purpose RG and suicide gene } \\
\text { 2. Available RPs with good pharma- } \\
\text { cokinetics } \\
\text { 3. May be used in patients receiving } \\
\text { Penciclovir }\end{array}$ & $\begin{array}{l}\text { 1. Currently, lower sensitivity than } \\
\text { HSV1-tk and mutants } \\
\text { 2. Available probes don't cross the BBB } \\
\text { 3. High activity in organs involved in } \\
\text { clearance } \\
\text { 4. Deiodination of the radio-iodine la- } \\
\text { beled probes } \\
\text { 5. Possible perturbation of cell character- } \\
\text { istics like all other reporter genes }\end{array}$ \\
\hline $\begin{array}{l}\text { Truncated mutant deox- } \\
\text { ycytidine kinase } \\
(\mathrm{h} \triangle \mathrm{dCKDM})\end{array}$ & {$\left[{ }^{18} \mathrm{~F}\right] \mathrm{FEAU}$} & $\begin{array}{l}\text { 1. May be used in patients receiving } \\
\text { Penciclovir }\end{array}$ & $\begin{array}{l}\text { 1. Probe doesn't cross the BBB } \\
\text { 2. Possible perturbation of cell character- } \\
\text { istics like all other reporter genes }\end{array}$ \\
\hline $\begin{array}{l}\text { Dopamine } 2 \text { Receptor }\left(\mathrm{D}_{2} \mathrm{R}\right) \\
\text { Mutant } \mathrm{D}_{2} \mathrm{R}\end{array}$ & $\begin{array}{l}{\left[{ }^{18} \mathrm{~F}\right] \mathrm{FESP}} \\
\text { Also potentially: } \\
{\left[{ }^{11} \mathrm{C}\right] \text { Raclopride }} \\
{\left[{ }^{11} \mathrm{C}\right] \text { N-methylspiperone }}\end{array}$ & $\begin{array}{l}\text { 1. Non-mutated human gene is not } \\
\text { immunogenic } \\
\text { 2. [18F]FESP can be used in humans } \\
\text { and has good pharmacokinetics } \\
\text { 3. Probe can cross BBB } \\
\text { 4. Binding of FESP to mutant } \mathrm{D}_{2} \mathrm{R} \text { does } \\
\text { not cause signal transduction }\end{array}$ & $\begin{array}{l}\text { 1. High background in Pituatory and } \\
\text { Striatum } \\
\left.\text { 2. Long wait time for }{ }^{18} \mathrm{~F}\right] \mathrm{FESP} \text { clearance }\end{array}$ \\
\hline $\begin{array}{l}\text { Human estrogen receptor a } \\
\text { ligand binding domain } \\
\text { (hERL) }\end{array}$ & {$\left[{ }^{18} \mathrm{~F}\right] \mathrm{FES}$} & $\begin{array}{l}\text { 1. Probe can cross BBB } \\
\text { 2. Probe used in clinic } \\
\text { 3. hERL lacks activity as a transcrip- } \\
\text { tion factor }\end{array}$ & $\begin{array}{l}\text { 1. Estrogen receptor is over-expressed in } \\
\text { uterus, ovaries, mammary gland and } \\
\text { breast cancer cells }\end{array}$ \\
\hline $\begin{array}{l}\text { Human somatostatin re- } \\
\text { ceptor subtype } 2 \text { (hSSTr2) }\end{array}$ & ${ }^{68} \mathrm{Ga}-\mathrm{DOTATOC}$ & $\begin{array}{l}\text { 1. The PRP has good pharmacokinet- } \\
\text { ics and has already undergone clinical } \\
\text { testing }\end{array}$ & $\begin{array}{l}\text { 1. Somatostatin binding to hSSTr2 can } \\
\text { cause cell signaling; hence expression } \\
\text { may perturb cell characteristics } \\
\text { 2. Some tumors and tissues express } \\
\text { hSSTr2 }\end{array}$ \\
\hline $\begin{array}{l}\text { Recombinant human car- } \\
\text { cinoembryonic antigen } \\
\text { (CEA) }\end{array}$ & $\begin{array}{l}\text { Iodine-124 labeled An- } \\
\text { ti-CEA scFv-Fc } \\
\text { H310A antibody frag- } \\
\text { ment }\end{array}$ & $\begin{array}{l}\text { 1. Not expressed in normal adult hu- } \\
\text { man cells, except for colon lumen }\end{array}$ & $\begin{array}{l}\text { 1. Dehalogenation of probe } \\
\text { 2. Naturally overexpressed in carcinomas } \\
\text { 3. Long half-life makes unsuitable for } \\
\text { dynamic imaging } \\
\text { 4. Probe cannot image in CNS }\end{array}$ \\
\hline $\begin{array}{l}\text { Engineered antibody frag- } \\
\text { ments: DAbR1 }\end{array}$ & ${ }^{86} \mathrm{Y}-\mathrm{AABD}$ & $\begin{array}{l}\text { 1. Humanized IRG } \\
\text { 2. High sensitivity }\end{array}$ & $\begin{array}{l}\text { 1. Possibly immunogenic } \\
\text { 2. }{ }^{86} \mathrm{Y} \text { is not a good PET radioisotope }\end{array}$ \\
\hline $\begin{array}{l}\text { Humanized membrane } \\
\text { anchored anti-polyethylene } \\
\text { glycol (PEG) }\end{array}$ & 124I-PEG-SHPP & $\begin{array}{l}\text { 1. A universal IRG allowing imaging } \\
\text { by PET, MRI and optical probes } \\
\text { 2. PEG is non-toxic and FDA ap- } \\
\text { proved }\end{array}$ & $\begin{array}{l}\text { 1. Long half-life of iodine does not allow } \\
\text { dynamic imaging of molecular events. } \\
\text { 2. Potential deiodination. }\end{array}$ \\
\hline $\begin{array}{l}\text { Sodium Iodide Symporter } \\
\text { (NIS) }\end{array}$ & 124I & $\begin{array}{l}\text { 1. Lack of immune reaction } \\
\text { 2. Easy to obtain probes } \\
\text { 3. Dual purpose as a reporter gene and } \\
\text { a therapeutic transgene }\end{array}$ & $\begin{array}{l}\text { 1. Naturally expressed in thyroid, stom- } \\
\text { ach, salivary glands, mammary glands, } \\
\text { and sometimes breast cells } \\
\text { 2. Probes are not trapped and can efflux, } \\
\text { short imaging window }\end{array}$ \\
\hline $\begin{array}{l}\text { Human norepinephrine } \\
\text { transporter (hNET) }\end{array}$ & {$\left[{ }^{124} \mathrm{I}\right] \mathrm{MIBG}$} & 1. Probes clinically used & $\begin{array}{l}\text { 1. High normal tissue background, since } \\
\text { hNET is expressed in many normal tis- } \\
\text { sues } \\
\text { 2. Induced hNET expression will likely } \\
\text { change cell biological function }\end{array}$ \\
\hline
\end{tabular}




\section{PET Reporter Genes Derived From Viruses and Other Non-Human Sources}

Herpes simplex virus 1 thymidine kinase (HSV1-tk) and its mutant derivatives have thus far been the most extensively studied and applied PET IRGs. These PET IRGs encode enzymes that catalyze phosphorylation reactions causing entrapment of their probes inside cells expressing them (Figure 2A). The specific PRPs for these PET IRGs are poor substrates for mammalian thymidine kinase 1 ; hence they will not be trapped within cells that don't express HSV1-tk or its mutants. Enzyme based PET IRGs have high sensitivity because each enzyme can catalyze many phosphorylation reactions causing signal amplification. However, in PET, target to background activity ratios determine the true sensitivity of the imaging assay.

Over the last 15 years, mutants of HSV1-tk have been created to increase sensitivity, reduce affinity for thymidine, increase affinity for some PRPs while eliminating affinity for other PRPs, and shorten the half-life of the PET IRGs. ${ }^{18-25}$ New PRPs have been synthesized and evaluated to increase affinity for either HSV1-tk or its mutants and reduce background activity in some organs such as liver or gut. ${ }^{26-33}$ Most of these PRPs (such as for instance, [ $\left.{ }^{18} \mathrm{~F}\right] \mathrm{FHBG}$ and $\left.\left[{ }^{18} \mathrm{~F}\right] \mathrm{FEAU}\right)$ were labeled with fluorine- 18 , while some others (for instance [124I]FIAU) were labeled with Iodine-124). Fluorine-18 has a short half-life of $\sim 110$ minutes; whereas Iodine-124 has a long half-life of 4.18 days. As an advantage, fluorine-18 labeled PRPs permit imaging on two consecutive days and are more suitable for monitoring time variation of therapeutic transgene expression or therapeutic cell biodistribution than iodine-124 labeled probes.

The clinical utility of HSV1-tk has been studied in both cancer gene therapy and cancer cellular gene therapy trials.11,13-15,17 For example, the PRP 9-(4-18F-fluoro-3-[hydroxymethyl]butyl)guanine ([18 $\mathrm{F}] \mathrm{FHBG})$ has successfully detected adenovirally delivered HSV1-tk during suicide gene therapy of hepatocellular cancer and cytolytic T cells expressing HSV1-tk during cell therapy of glioblastoma.11,13 [18F]FHBG has a FDA approved IND (IND\#61,880) and a published protocol for performing [ $\left.{ }^{18} \mathrm{~F}\right] \mathrm{FHBG}$ PET scans in humans is available. ${ }^{17,34,35}$

HSV1-tk and its mutants have several advantages for gene and cellular gene therapy applications. Many PET and single photon emission computerized tomography (SPECT) reporter probes are available with suitable pharmacokinetics in rodents, pigs and humans. Several of the available PRPs exhibit relatively low background activity in mamma- lian cells and tissues (because they are poor substrates for mammalian TK1). They have multiple utilities as PET IRGs, suicide genes (i.e. genes that can activate pro-drugs and make them toxic to for instance cancer cells) and safety genes (can be used through their suicide mechanism to eradicate therapeutic cells, if they cause an adverse effect). ${ }^{36}$ In addition, these enzyme/radionuclide based PET IRG/PRP systems have been validated for imaging of a variety of molecular events, non-invasively, in living mammals, including humans.

Nevertheless, HSV1-tk and its mutants have shortcomings that limit their utility. One limitation is the potential immunogenicity of HSV1-tk and its mutants that limits their application in immuno-competent hosts. For example, an immune reaction to the protein products of these PET IRGs may cause pre-mature elimination of the therapeutic cells that are expressing them. ${ }^{37,38}$ Therefore, as discussed later in this review, human derived PET IRGs have been and are being developed to address these limitations.

Another limitation is that the PRPs do not cross the blood brain barrier (BBB); hence they may not be useful in cases where therapeutic transgenes or cells are targeted to sites within the central nervous system. For example, they may not be useful for monitoring the kinetics of therapeutic stem cells administered for the treatment of some neurodegenerative disorders. Finally, improvements in imaging sensitivity of HSV1-tk, its mutants and other PET IRGs, would increase their utility in monitoring therapeutic transgene or cell kinetics.

Two other PET IRGs of non-human origin, the Varicella-Zoster virus thymidine kinase (VZV-tk) and LacZ will likely encounter immunogenicity issues. ${ }^{39,40}$ The VZV-tk PET IRG was developed with the hope that its PRPs bicyclic nucleoside analogues (BCNA) could cross the BBB. However, this approach failed. The Lac $Z$ gene encodes the bacterial $\beta$-Galactosidase $(\beta-G a l)$ enzyme, used as a reporter gene (RG) for in vitro studies with chromogenic and fluorogenic reporter probes and can also serve as a MRI reporter gene. ${ }^{41-43}$ However, thus far all PRPs designed for $\beta$-Gal either do not cross cell membranes or are not specific. ${ }^{40}$ Therefore, amongst PET IRGs that do not have a human gene counterpart, HSV1-tk and its optimized mutants and PRPs still represent the most useful PET IRG systems and they should serve as essential tools for non-invasive pharmacokinetics monitoring in both cell and gene therapy investigations.

\section{Potentially Non- Immunogenic PET-IRGs}

Immunogenicity toward proteins encoded by reporter genes can cause major problems in therapeu- 
tic transgene or cell kinetics monitoring studies. In gene therapy, it may shorten the duration of PET IRG expression. In cell or cellular gene therapy, it may cause pre-mature eradication of the therapeutic cells expressing the PET IRG. Several genes encoding protein receptors, transporters and kinases have been investigated that might serve as non-immunogenic PET IRGs in humans. Alternatively, they might have mammalian species specific counterparts that can be used without rejection in immunocompetent animal research models. ${ }^{44}$ These include dopamine type 2 receptor $\left(D_{2} R\right)^{45-48}$, human estrogen receptor $\alpha$ ligand binding domain (hERL) ${ }^{49,50}$, human type 2 somatostatin receptor (hSSTr2) ${ }^{51-54}$, recombinant carcinoembryonic antigen $(\mathrm{CEA})^{55}$, engineered antibody fragments ${ }^{56}$, sodium iodide symporter (NIS) ${ }^{57-61}$, human norepinephrine transporter (hNET) ${ }^{62}$, human mitochondrial thymidine kinase type 2 (hmtk2) ${ }^{63,64}$, mutant deoxycytidine kinases 65 , and anti-polyethylene glycol (anti-PEG) ${ }^{6}$.

However, the use of such endogenous human genes as PET IRGs has two potential problems: first, the PRP can also accumulate in cells that express the endogenous gene; second, the PET IRG would function like the endogenous gene and thus perturb the cells in which it is expressed. Moreover, it is still unknown whether these PET IRG's are immunogenic. To overcome these problems mutations have been introduced to eliminate their function. ${ }^{47}$ Moreover, specific mutations have been designed to increase their detection sensitivity with specific PRPs. 65 The human mitochondrial thymidine kinase 2 (hmtk2) represents an attractive candidate PET IRG. Even though hmtk2 is ubiquitously expressed in the mitochondria of mammalian cells, it is not accessible to uracil nucleoside analogs that are its substrates. Therefore, a truncated version of hmtk 2 that can be expressed in the cytoplasm can serve as a potentially non-immunogenic PRG, without non-specific accumulation of its PRPs. ${ }^{63}$ We have recently designed double mutants of truncated hmtk2 that combined with its PRP [ $\left.{ }^{18} \mathrm{~F}\right] \mathrm{L}-\mathrm{FMAU}$ has a sensitivity comparable to HSV1-tsr39tk/[18F]FHBG and reduced potential for cell perturbations or immunogenicity in humans. ${ }^{64}$

\section{Imaging Therapeutic Transgenes}

Therapeutic transgenes (TGs) are delivered into living organisms either directly or by using cells as vectors, which are then delivered into the mammal. There are two approaches to image the expression of TGs with PET: 1) If a specific PET probe is available, the mRNA or protein encoded by the TG can be detected directly (Figure 4). ${ }^{36,67}$ 2) If a specific PET probe is not available, the TG can be imaged indirectly by linking its expression to the expression of a PET IRG. The direct approach can be used to monitor expression of HSV1-tk or its mutant HSV1-sr39tk during suicide gene therapy of cancer (Figure 5), since several specific PET probes are available for detecting the enzymes encoded by these TGs/PET IRGs. $13,14,25,36,68-71$ However, specific PET probes are not available for most TGs and the costs of developing new specific PET probes for each TG are high; hence the second approach of indirect imaging with PET IRGs may be more practical.

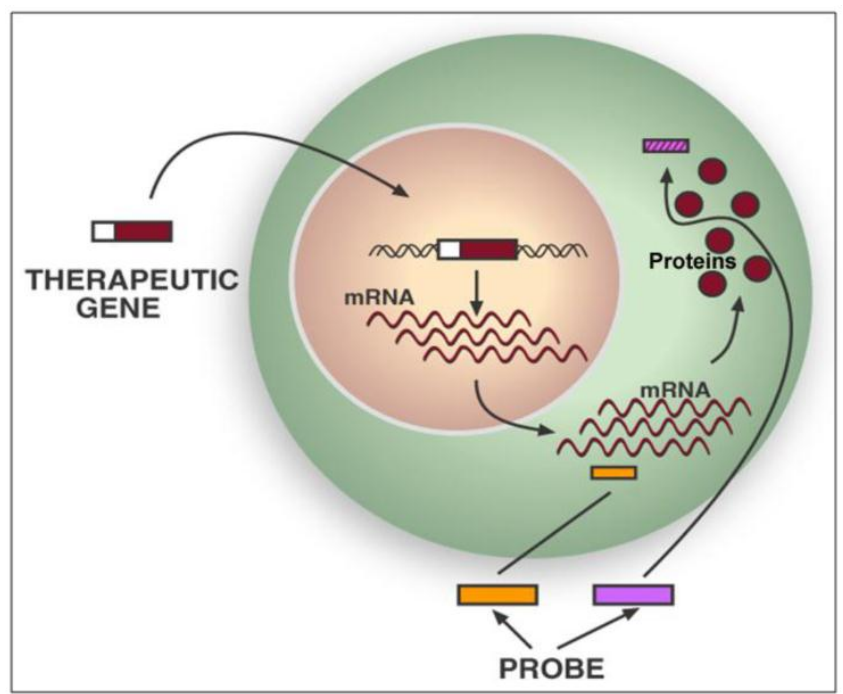

Fig. 4. Direct imaging of a therapeutic transgene's products with PET. Specific PET probes may be designed and developed to directly image the messenger ribonucleic acids (mRNA) transcribed from a therapeutic transgene (TG) or the protein translated from its mRNA. Examples of potential mRNA PET imaging probes are radiolabeled antisense oligo-nucleotides (RASONs) or modifications of RASONs that are complementary to a specific region of an mRNA. There are also PET imaging probes that specifically detect a certain protein by binding to it or even detect the protein's function. Examples are specific detection of $\mathrm{D}_{2} \mathrm{R}$ with $\left[{ }^{18} \mathrm{~F}\right] \mathrm{FESP}$ and specific detection of HSVI-sr39TK enzyme activity with [18F]FHBG. However, developing a new specific PET probe to image the expression of any TG requires significant expenditure of resources and may not be practical. 


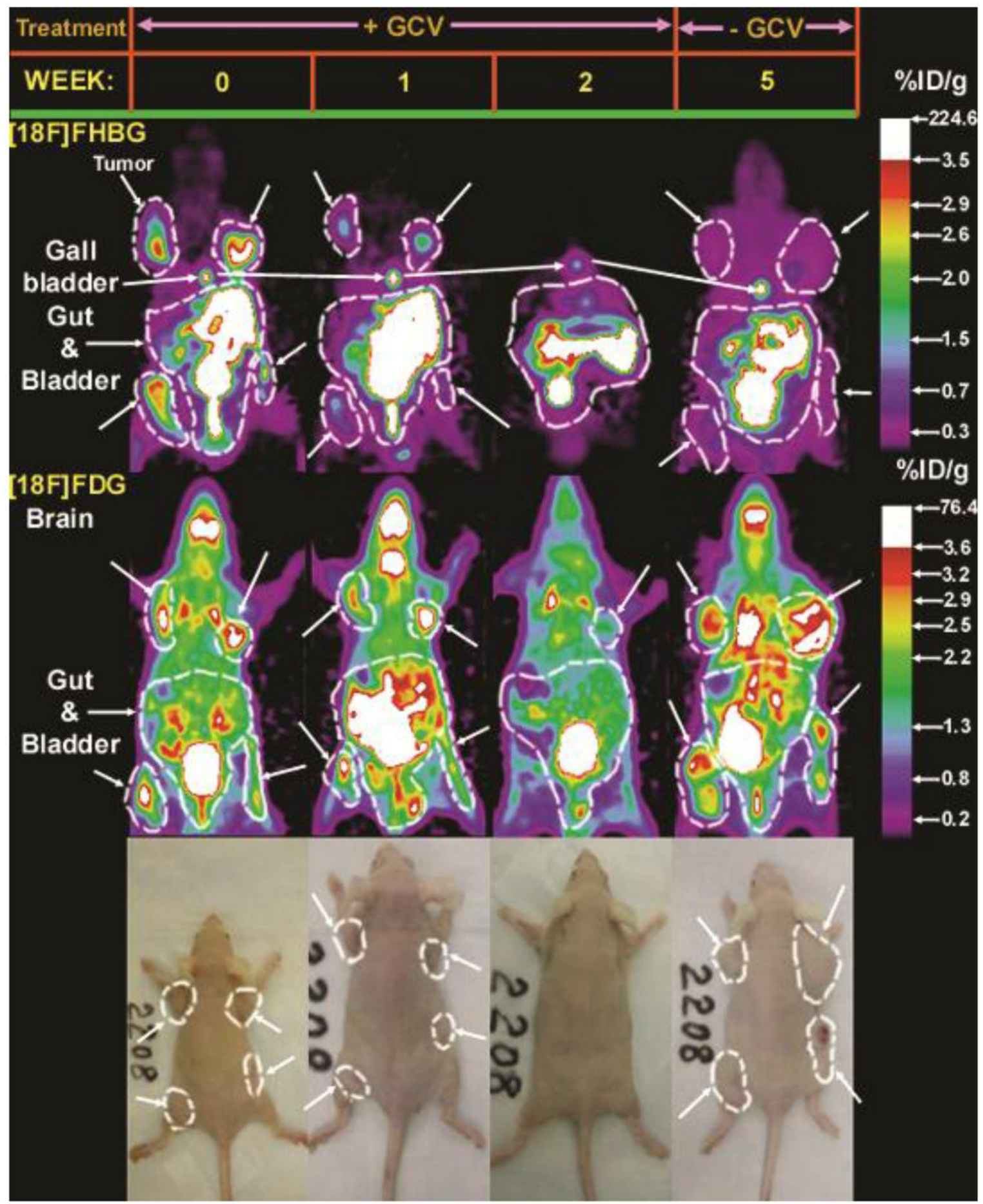

Fig. 5. Example of direct gene therapy monitoring with PET. Direct imaging of HSVI-sr39tk/GCV suicide gene therapy progress in $\mathrm{C} 6$ glioma xenografted immunodeficient mice. Four C6sr39 tumor xenografts were implanted subcutaneously on 4 sites of the nude mouse shown. All 4 tumors highly accumulated [ $\left.{ }^{18} \mathrm{~F}\right] \mathrm{FHBG}$ and [18F]FDG prior to starting GCV treatment (week 0 ). The mouse was administered daily IP injections of GCV (I00 mg/kg) for two weeks, during which time period the tumors regressed (3 of them visually eradicated) and [ $\left.{ }^{18} \mathrm{~F}\right] \mathrm{FHBG}$ and $\left[{ }^{18} \mathrm{~F}\right] \mathrm{FDG}$ accumulation declined to background levels. The mouse was monitored up to three weeks after halting GCV treatment. The tumors re-grew, but only accumulated $\left[{ }^{18} \mathrm{~F}\right] \mathrm{FHBG}$ at background levels, despite robust ability to accumulate [18F]FDG. Reprinted from research article by Yaghoubi et al. ${ }^{36}$ 


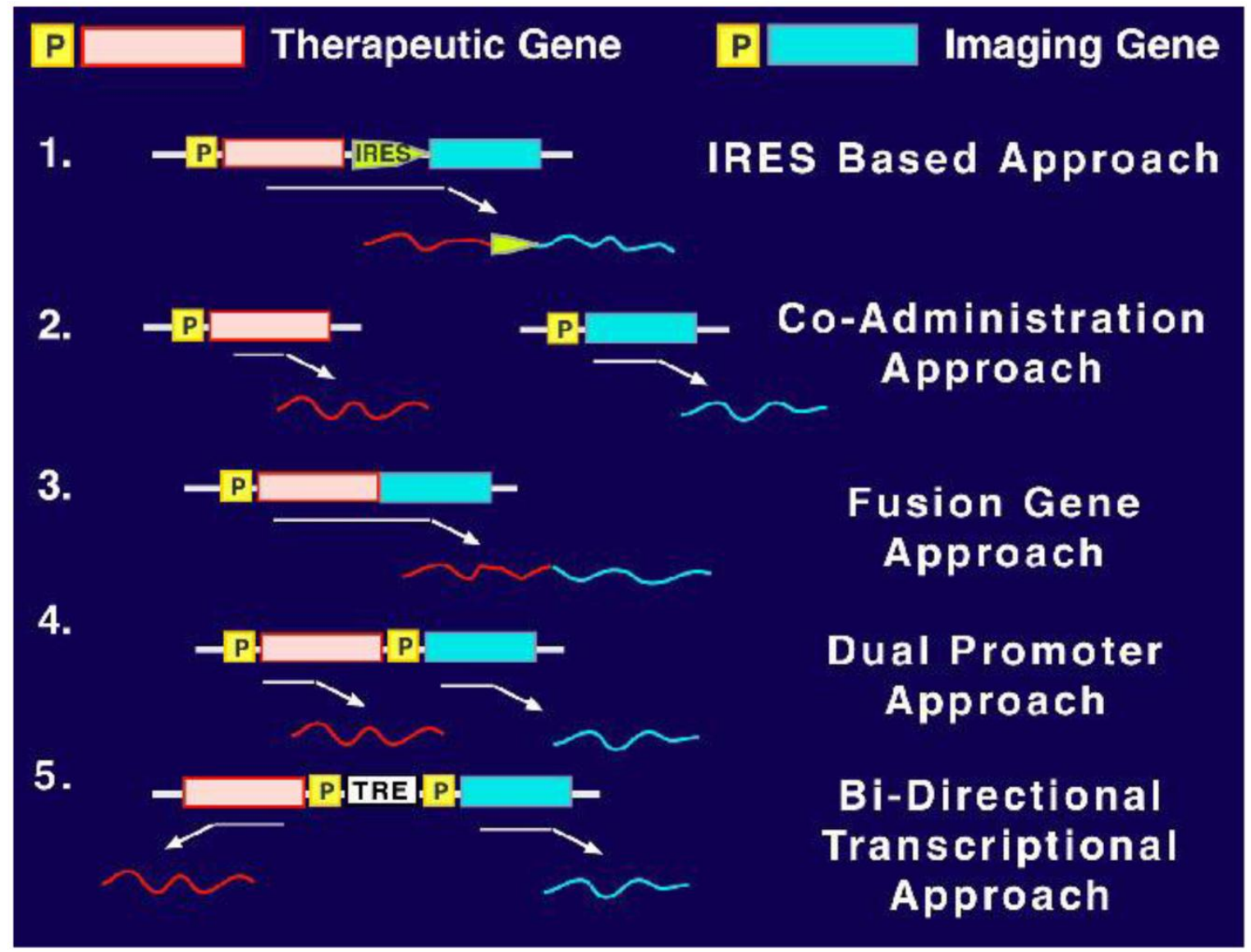

Fig. 6. Five genetic constructs enabling linkage of the expression of a therapeutic transgene to a PET imaging reporter transgene for indirect monitoring of the pharmacokinetics of the therapeutic transgene. Depending on the therapeutic transgene and the PET imaging reporter transgene used these constructs should allow expression of both transgenes in a correlated manner in a population of cells. Reprinted from figure 9.5 of a book chapter by Yaghoubi et al. ${ }^{9}$

Five techniques are available for linking the expression of a transgene with a PET IRG for indirect imaging (Figure 6). ${ }^{46,72-80}$ The first, internal ribosomal entry site (IRES) based approach, involves the use of a single gene expression regulatory element to derive the mRNA expression of both the TG and the PET IRG, while the IRES enables the translation of two separate proteins encoded by these transgenes. This approach has been validated and shown to yield correlated detection of the two proteins encoded by two IRGs that were linked in this manner. ${ }^{46,75,78,79,81}$ Usually, the TG is inserted upstream of the IRES and the PET IRG would be inserted downstream of the IRES to avoid attenuation of TG expression that may occur when a transgene is downstream the IRES. The disadvantage is that attenuated expression of the PET IRG would reduce detection sensitivity. This approach is mostly suitable when one wants every single cell that has the TG to also have the PET IRG, but wants to avoid any interference with the protein encoded by the TG.
The second co-administration approach employs two identical transgene delivery vectors containing identical gene expression regulatory elements, one carrying the PET IRG and the other carrying the TG. This simple approach works because PET can only image a population of cells that would have equal access to and the ability to take up both transgene delivery vectors. ${ }^{73,76}$ In fact, Yaghoubi et al. initially demonstrated that when various equivalent titers of two identical adenoviruses, one carrying HSV1-sr39tk and the other carrying $D_{2} R$, are co-delivered by intravenous injections into lateral tail veins of mice, a good correlation is observed between activities of $\left.{ }^{18} \mathrm{~F}\right] \mathrm{FHBG}$ or $\left.{ }^{18} \mathrm{~F}\right] \mathrm{FESP}$ in the livers of these mice (Figures 7A\&B). ${ }^{73}$ This approach may be ideal when the vector containing the TG has already been validated and one does not want to alter the vector to also include a PET IRG; hence one would produce an identical vector containing the PET IRG to co-administer with the vector carrying the TG, thereby tracking the kinetics of TG expression indirectly. 
A:

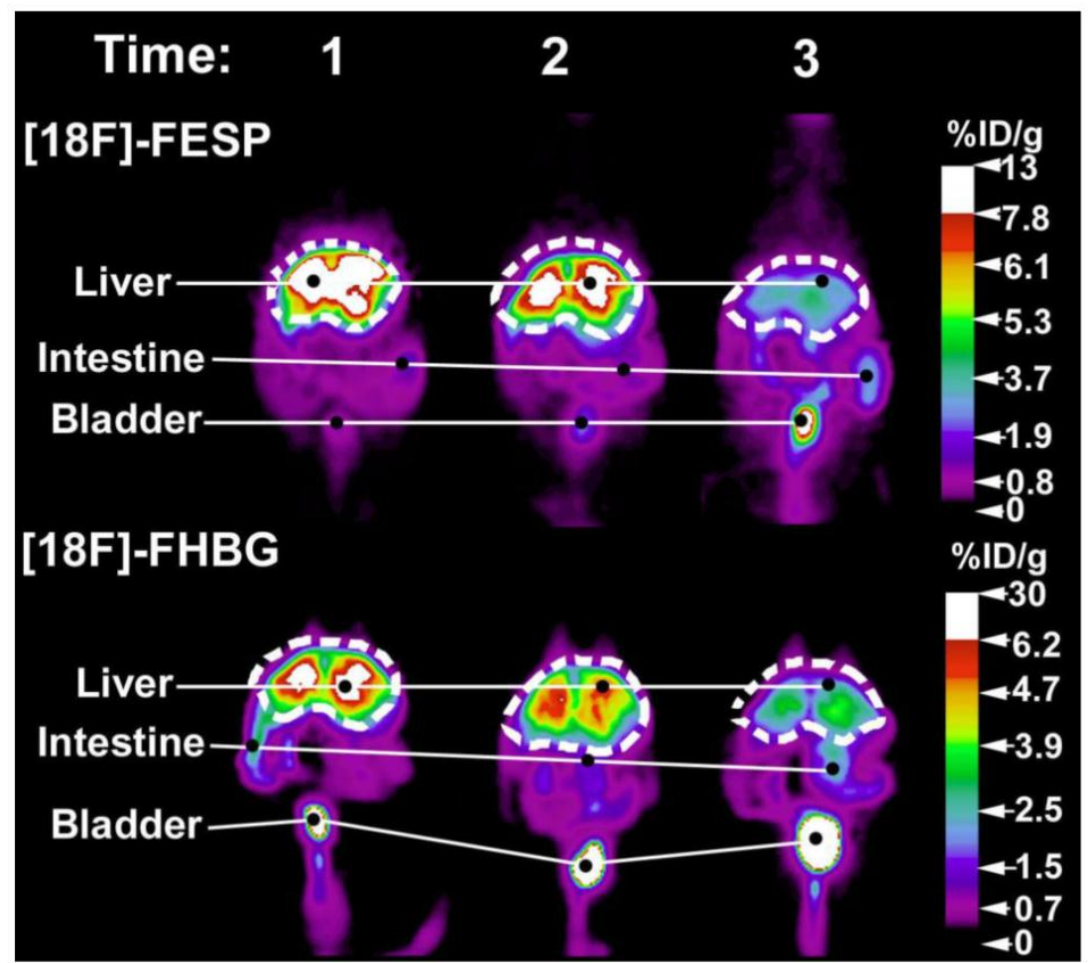

B:

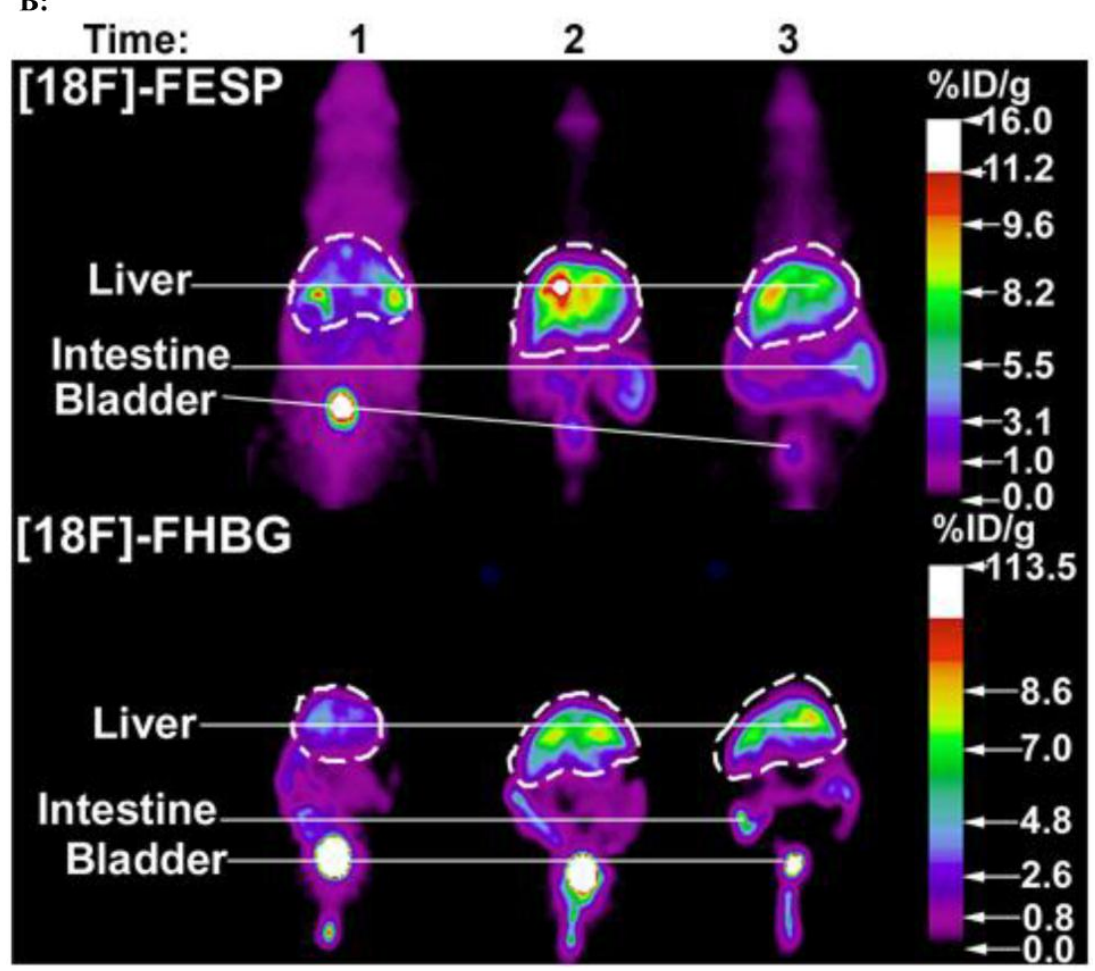

Fig. 7. $\left[{ }^{18} \mathrm{~F}\right] \mathrm{FESP}$ and $\left[{ }^{18} \mathrm{~F}\right] \mathrm{FHBG}$ coronal images of $(\mathrm{A})$ a Swiss Webster and (B) a Nude mouse at three different time points after co-injecting equivalent titers of Ad-CMV-HSVI-sr39tk and Ad-CMV- $\mathbf{D}_{2} \mathbf{R}$ intravenously. (A) $2.0 \times 10^{9}$ and (B) $0.1 \times 10^{9}$ pfu of both Ad-CMV-D 2 R and Ad-CMV-HSVI-sr39tk were co-injected into the tail vein of a Swiss Webster mouse and a Nude mouse, respectively. The mice were then scanned for [ $\left.{ }^{18} \mathrm{~F}\right] \mathrm{FESP}$ and $\left[{ }^{18 \mathrm{~F}}\right] \mathrm{FHBG}$ activity. For the $\left[{ }^{18} \mathrm{~F}\right] \mathrm{FESP}$ images times I, 2 , and 3 correspond to 3, 10, and 24 days after the injection of the adenoviruses, respectively. For the [18F]FHBG images times I, 2, and 3 correspond to 5,12 , and 26 days after the injection of the adenoviruses, respectively. The images are scaled for injected dose. These mice were representatives of a larger data set. Reprinted from research article by Yaghoubi et al.73 
The third, a fusion gene approach involves inserting the TG and IRG next to each other, regulated by a single promoter, such that a single encoded mRNA and fusion protein contains the product of both transgenes. Interestingly, this technique has not yet been evaluated for imaging a TG, using PET IRGs, but lead to the development of multimodality IRG constructs. ${ }^{82-88}$ The main problem with this approach is that the quaternary structure of the fusion protein may significantly alter the function of the protein encoded by the TG and significantly reduce detection sensitivity of the protein encoded by the PET-IRG. Therefore, this approach may be ideal if lack of protein function alteration can be confirmed, because it may yield the best correlation between the expression of TG and PET IRG.

The forth, dual promoter, approach involves inserting both the TG and the PET IRG on the same construct each having its own separate but identical promoter. ${ }^{89}$ This approach also ensures single cell co-delivery and translation of separate proteins from the mRNAs encoded by the PET IRG and the TG.

The fifth, bidirectional transcriptional approach involves inserting the RG and TG on opposite sides of a bidirectional regulatory element, each having its own separate but identical minimal promoter. ${ }^{77,80}$ This approach is most suitable when transgene expression needs to be up or down regulated at different time points. For a detailed discussion of advantages and disadvantages of each approach we refer the reader to a book chapter by Yaghoubi and Gambhir. ${ }^{9}$

\section{Imaging Genetically Modified Therapeutic Cells}

Adoptive cellular gene therapy is a promising approach for treating a variety of diseases, including neurodegenerative, cardiovascular and autoimmune disorders as well as cancer. ${ }^{90-93}$ Targeted therapeutic cells (TCs) are injected into patients to restore normal organ function in degenerative diseases, eliminate cancer cells, or correct a system malfunction in other diseases. Selection of appropriate cells, optimization of the cells to perform a specific therapeutic function and determination of an appropriate administration route and cell dose are necessary to achieve the desired therapeutic effect.

To successfully implement new cell therapy protocols, non-invasive techniques are needed for studying whole-body kinetics of TCs. Such monitoring would provide information regarding presence, location, quantity, proliferation, survival and status of TCs in animals or patients at any desired time-point following administration of TCs. This expanded type of kinetic analysis is impossible with conventional methods that require euthanization of research animals, or conventional clinical methods that require collection of multiple sequential biopsy samples from humans. Molecular imaging of TCs pre-labeled with imaging probes is insufficient as it will not yield information about TC survival, proliferation and change in characteristics (TC status). ${ }^{94-100}$

Currently, only PET or SPECT IRGs are generalizable tools for non-invasive imaging of all aspects of TC kinetics in mammals larger than rats. ${ }^{4,5,8,101}$ To use PET IRG imaging for monitoring the biodistribution, survival, proliferation and estimate quantities of $\mathrm{TCs}$, these cells are first genetically engineered ex vivo to stably express a PET IRG under the control of a strong constitutive promoter. Then, at desired time points, following adoptive transfer of the genetically modified TCs, the PET reporter probe is injected and the recipient of the TCs is scanned with PET (Figure 8). PET IRGs have been used to monitor the kinetics of various potential TCs, including immune cells, stem cells and pancreatic islets, in pre-clinical living animal models. ${ }^{102-123}$ Therefore, PET IRGs are valuable tools, one should use during development of cellular gene therapy techniques for treatment of cancer and autoimmune, cardiovascular and neurological disorders.

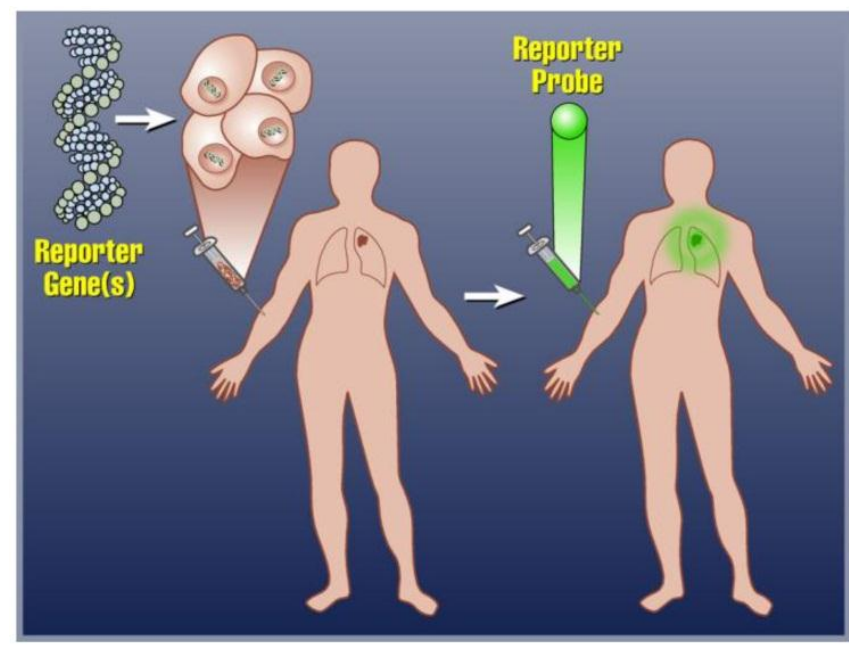

Fig. 8. PET IRG based imaging of the kinetics of a TC population. TCs are genetically engineered to stably express the PET IRG ex vivo. Following confirmation of PET IRG expression TCs are injected into the living subject. At any desired time point after TC administration the specific PRP is injected into the living subject and the subject is scanned for the biodistribution of the PRP. Quantitative PRP biodistribution analysis then allows studying the kinetics of the TCs in the subject.

\section{Clinical Translation of PET Reporter Gene Imaging}

The sensitivity of PET IRGs is higher than that of 
optical IRGs in animals larger than mice, because gamma rays readily penetrate tissues. Furthermore, their sensitivity is higher than that of MRI IRGs in all mammals. Therefore, they can be used for gene and cell therapy clinical applications. In fact, radionuclide based IRGs, have thus far been the only IRGs able to provide whole-body images of transgene expression in humans.

Using [124I]FIAU, Jacob's et al. successfully imaged non-virally administered HSV1-tk inside glioma tumor of a patient. ${ }^{15}$ In another study, Yaghoubi et al. reported the pharmacokinetics, safety and dosimetry of $\left[{ }^{18} \mathrm{~F}\right] \mathrm{FHBG}$ in healthy human volunteers. ${ }^{17}$ Subsequently, adenovirally delivered HSV1-tk was imaged in hepatocellular carcinoma. ${ }^{12,13} \mathrm{~A}$ specific $\left[{ }^{18} \mathrm{~F}\right] \mathrm{FHBG}$ signal was observed at tumor injection sites when $>$ $10^{12}$ particles of adenovirus had been injected intratumorally. Interestingly, only patients who received > $10^{12}$ particles and had been treated with valganciclovir had stable disease while those receiving lower particle numbers did not respond to treatment. In 2004, all required pre-clinical safety, dosimetry and toxicity studies for [ $\left.{ }^{18} \mathrm{~F}\right] \mathrm{FHBG}$ were completed and an investigational new drug (IND) approval was granted by US FDA. ${ }^{34}$ This enabled the first clinical trial of reporter gene based cell imaging in patients with glioma. In this study, the gliomas were first resected and a total of $10^{9}$ potentially therapeutic autologous cytolytic T cells (CTLs) that stably expressed HSV1-tk were then injected into the resection cavity over a period of 5 weeks (Figure 9A). Following infusion of all the cells a whole-body [18F]FHBG PET scan was performed. This first imaging study showed above background $\left.{ }^{18} \mathrm{~F}\right] \mathrm{FHBG}$ signal at the site of cytolytic $\mathrm{T}$ cell infusions and revealed trafficking of these cells to a remote recurrent tumor in the patient's corpus callosum (Figure 9B). ${ }^{11}$ This study has set the stage for future studies, using $\left.{ }^{18}{ }^{18} \mathrm{~F}\right] \mathrm{FHBG}$ PET for imaging biodistribution of genetically engineered therapeutic cells in patients and such clinical studies are planned at multiple medical centers in the United States. A published peer-reviewed protocol for imaging humans with $\left[{ }^{18} \mathrm{~F}\right] \mathrm{FHBG}$ is available. ${ }^{35}$

\section{Future Directions}

A major goal for PET IRGs and their probes is their wide-spread adoption by academic and industry developers of various cell and gene therapy approaches. We believe, this requires close and early collaborations between molecular imagers and cell/gene therapists. This would afford a parallel approach starting with pre-clinical studies so that PET reporter gene imaging can be incorporated into the cell or gene therapy investigational new drug proto- col. Early collaboration is also needed for optimizing the delivery of the PET IRG for the specific cell or gene therapy approach. Safe and stable PET reporter transgene delivery for clinical applications is a major hindrance to adoption and will be better addressed when molecular imagers and gene therapists collaborate early. Early collaboration may also help resolve another hindrance to clinical translation, which is efficient delivery of PET IRGs into primary cells that cannot be cultured ex vivo for long periods of expansions.

The hope for not too distant future of this invaluable technology is exponential growth in its use in cell and gene therapy clinical trials. This is likely to happen soon as additional non-immunogenic PET IRGs with high sensitivity probes become available. Improvements to the currently existing PET IRGs would also help broaden their use in cell and gene therapy trials. PRPs with better pharmacokinetics, with reduced backgrounds and increased bioavailability would also enhance the application of PET IRG based cell and transgene imaging. However, again working early with IRG experts, gene and cell therapists will be able to choose the most suitable currently available PET IRG/PRP system that would allow progression into clinical trials.

A new molecular-genetic imaging industry is emerging with the aim of educating therapeutics firms and regulatory agencies about the applications of imaging reporter genes and expanding their use in clinical trials. For example, CellSight Technologies located in California, USA was founded for this mission. A world-wide effort is underway, in North America, Europe, Southeast Asia and Australia to improve PET IRG technologies and satisfy requirements for getting them into clinical trials.

Many of the gene and cellular gene therapy treatments currently listed on clinical trials.gov would benefit from PET IRG based transgene or cell kinetics monitoring. Of course, pre-clinical imaging studies would be required before incorporation of the imaging studies in the clinical trials. Table 3 lists some of the treatments that are currently recruiting for clinical trials that would benefit from PET IRG based imaging. In these studies PET-IRG based imaging would reveal the locations of genetically engineered cells administered for treatment and would inform early on whether appropriate targeting has occurred; hence enabling prediction of potential efficacy or adverse effects. As described in this review, PET IRG expression can also be linked to the expression of the therapeutic transgenes, which would enable monitoring the locations, magnitude and duration of expression of the therapeutic transgenes. Indeed in some cases 
linking is not even necessary. For example, some of the trials listed involve suicide gene therapy with HSV1-tk or radiation therapy following sodium iodide symporter gene therapy. Both of these therapeutic transgenes already have PRPs that can be used to

A: image them during clinical trials. As the value of PET IRG based imaging is recognized in the future, we expect utilization of these tools in many gene and cell therapy trials.

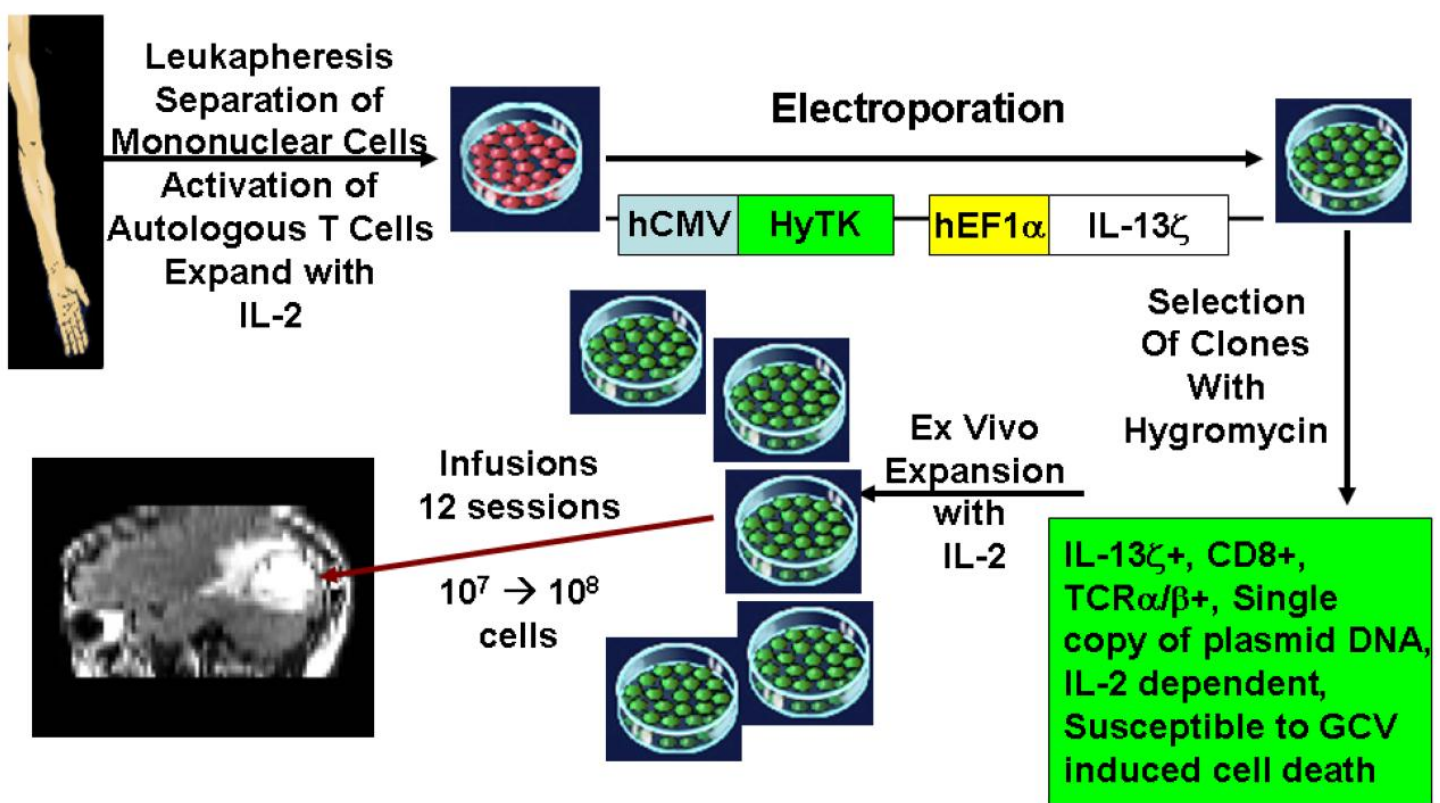

B:

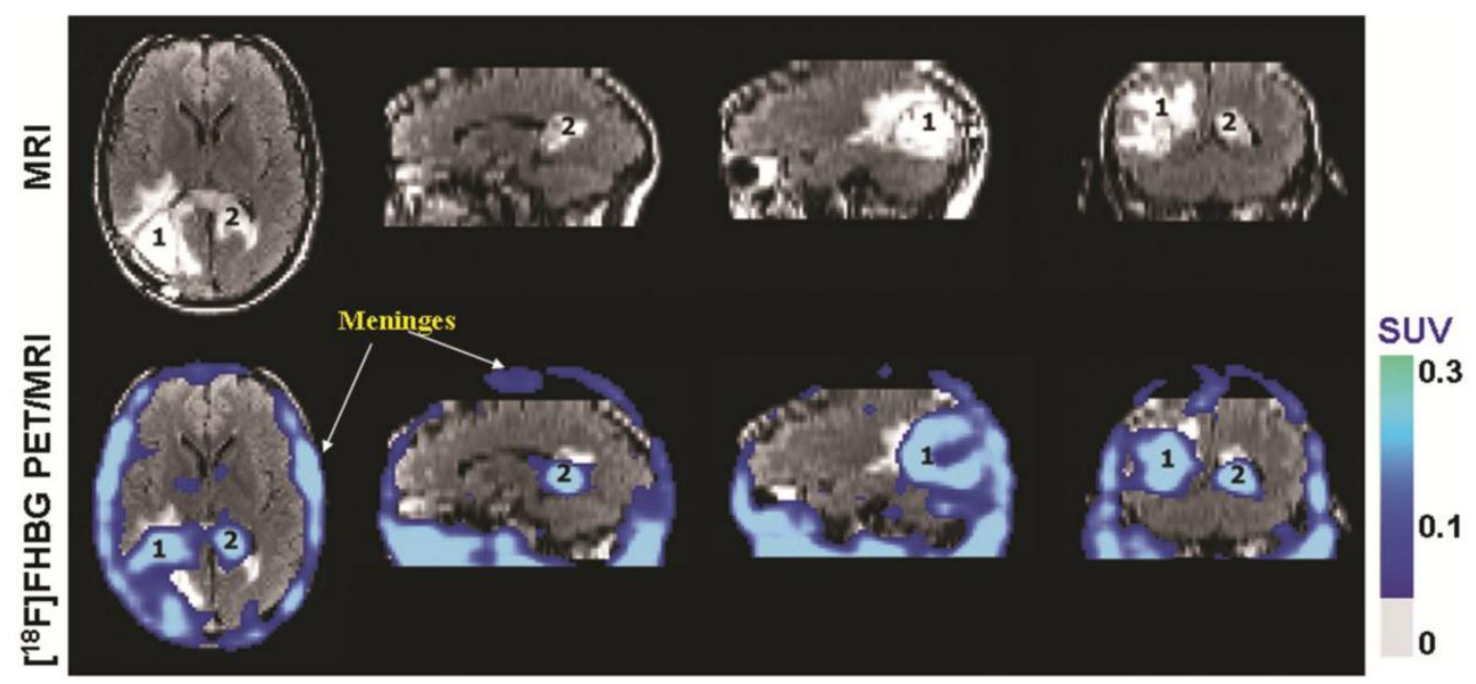

Fig. 9 (A). Description of the procedures involved in the preparation of genetically engineered CTLs and their infusion into the recurrent glioma tumor resection site. (B). MRI and PET over MRI superimposed brain images of a patient recieving genetically engineered cytolytic $T$ cells expressing HSVI-tk for imaging and safety purposes. Images were acquired approximately two hours after [ $\left.{ }^{18} \mathrm{~F}\right] \mathrm{FHBG}$ injection. The patient had a surgically resected tumor (I) in the right parietal lobe and a new non-resected tumor in the center (2), near corpus callosum of his brain. The infused cells had localized at the site of tumor I and also trafficked to tumor 2. [ $\left.{ }^{8} \mathrm{~F}\right] \mathrm{FHBG}$ activity is higher than the brain background at both sites. Background [ $\left.{ }^{18} \mathrm{~F}\right] \mathrm{FHBG}$ activity is low within the Central Nervous System due to its inability to cross the blood brain barrier. Background activity is relatively higher in all other tissues. Activity can also be observed in the meninges. The tumor $1 /$ meninges and tumor $2 /$ meninges [ $18 \mathrm{~F}] \mathrm{FHBG}$ activity ratio in this patient was $\mathrm{I} .75$ and $\mathrm{I} .57$, respectively. Whereas the average resected tumor site/meninges and intact tumor site to meninges [ $18 \mathrm{~F}$ ] FHBG activity ratio in control patients was 0.86 and 0.44 , respectively. Figure $9 \mathrm{~A}$ is a reprint of figure 13.9 from a book chapter by Penuelas et al. ${ }^{7}$ and Figure $9 \mathrm{~B}$ is a reprint of figure I from a case study report by Yaghoubi et al. 11 
Table 3: Currently recruiting gene/cellular gene therapy clinical trials that would benefit from PET IRG based kinetics monitoring in treatment development.

\begin{tabular}{|c|c|}
\hline Gene/Cell Therapeutic Agent & Treatment Target \\
\hline $\begin{array}{l}\text { Suicide Gene/Prodrugs: } \\
\text { Herpes Simplex virus type } 1 \text { thymidine kinase/Ganciclovir or Penciclovir } \\
\text { Sodium Iodine Symporter/Radio-iodine therapy } \\
\text { Purine Nucleoside Phosphosrylase/Fludarabine phosphate } \\
\text { Cytosine deaminase transgene/5-Fluorouracil }\end{array}$ & $\begin{array}{l}\text { Cancer } \\
\text { Eradication of malfunctioning cells administered into } \\
\text { patients }\end{array}$ \\
\hline $\begin{array}{l}\text { Adoptive cellular immune-gene therapy: } \\
\text { Genetically engineered T cells } \\
\text { Genetically engineered natural killer cells }\end{array}$ & $\begin{array}{l}\text { Cancer } \\
\text { AIDS }\end{array}$ \\
\hline Cell based vaccines & Cancer \\
\hline $\mathrm{CD} 4^{+}$cells expressing $\gamma$-globin & Sickle cell anemia and $\beta$-Thalassemia \\
\hline $\begin{array}{l}\text { Fanconi anemia complementation group A gene expressing hematopoietic stem } \\
\text { cells }\end{array}$ & Fanconi Anemia \\
\hline $\begin{array}{l}\text { Antiangiogenic Therapy: } \\
\text { Endostatin transgene } \\
\text { Anti-VEGF receptor CD8+ lymphocytes }\end{array}$ & Cancer \\
\hline Human endothelial nitric oxide synthase transgene & Pulmonary Hypertension \\
\hline Adenosine deaminase transgene & Severe Combined Immunodeficiency \\
\hline Gp91 transgene & Chronic Granulomatous Disease \\
\hline $\begin{array}{l}\text { Hematopoietic stem cells lentivirally transduced to express the Wiskott-Aldrich } \\
\text { syndrome protein encoding transgene }\end{array}$ & Wiskott-Aldrich syndrome \\
\hline Adenylyl cyclase type 6 transgene & Congestive Heart Failure \\
\hline Nerve growth factor transgenes & Alzheimer Disease \\
\hline Neurturin transgene & Parkinson's Disease \\
\hline Messenchymal stem cells & $\begin{array}{l}\text { Kidney transplant recipients } \\
\text { Cancer patients with kidney failure } \\
\text { Chronic graft vs host disease } \\
\text { Osteoarthritis }\end{array}$ \\
\hline Allogeneic stem cells & Severe Aplastic Anemia \\
\hline Autologous epidermal sheets engineered to express collagen type VII transgene & Recessive Dystrophic Epidermolysis Bullosa \\
\hline VEGF transgene & Critical Limb Ischemia \\
\hline Stem cell therapy & $\begin{array}{l}\text { Cardiovascular diseases } \\
\text { Multiple Sclerosis } \\
\text { Hereditary Ataxias } \\
\text { Myasthenia Gravis } \\
\text { Type 1\&2 Diabetes Mellitus } \\
\text { Liver Cirrhosis }\end{array}$ \\
\hline
\end{tabular}

\section{Competing Interests}

The authors have declared that no competing interest exists.

\section{References}

1. Herzog RW, Cao O, Srivastava A. Two decades of clinical gene therapy--success is finally mounting. Discovery Medicine 2010; 9: 105-111.

2. Hackett PB, Largaespada DA, Cooper LJ. A transposon and transposase system for human application. Mol Ther 2010; 18 : 674-683.

3. Al-Dosari MS, Gao X. Nonviral gene delivery: principle, limitations, and recent progress. AAPS J 2009; 11: 671-681.

4. Gambhir SS, Yaghoubi SS. Molecular Imaging With Reporter Genes. Cambridge University Press, 2010.

5. Acton PD, Zhou R. Imaging reporter genes for cell tracking with PET and SPECT. Quarterly Journal of Nuclear Medicine and Molecular Imaging 2005; 49: 349-360.
6. Herschman HR, MacLaren DC, Iyer M, Namavari M, Bobinski $\mathrm{K}$, Green LA et al. Seeing is believing: non-invasive, quantitative and repetitive imaging of reporter gene expression in living animals, using positron emission tomography. J Neurosci Res 2000; 59: 699-705.

7. Peñuelas I, Yaghoubi SS, Prósper F, Gambhir SS. Clinical applications of reporter gene technology. In: Yaghoubi SS, Gambhir SS (eds). Molecular Imaging With Reporter Genes. Cambridge University Press, 2010.

8. Serganova I, Blasberg R. Reporter gene imaging: potential impact on therapy. Nucl Med Biol 2005; 32: 763-780.

9. Yaghoubi SS, Gambhir SS. Gene therapy and imaging of transgene expression in living subjects. In: Yaghoubi SS, Gambhir SS, eds. Molecular Imaging With Reporter Genes. Cambridge University Press. 2010:227-238.

10. Ray P, Bauer E, Iyer M, Barrio JR, Satyamurthy N, Phelps ME et al. Monitoring gene therapy with reporter gene imaging. Semin Nucl Med 2001; 31: 312-320.

11. Yaghoubi SS, Jensen MC, Satyamurthy N, Budhiraja S, Paik D, Czernin J et al. Noninvasive detection of therapeutic cytolytic T 
cells with ${ }^{18} \mathrm{~F}-\mathrm{FHBG}$ in a patient with glioma. Nat Clin Pract Oncol 2009; 6: 53-58.

12. Penuelas I, Haberkorn U, Yaghoubi S, Gambhir S. Gene therapy imaging in patients for oncological applications. Eur J Nucl Med Mol Imaging 2005; 32: S384-S403.

13. Penuelas I, Mazzolini G, Boan JF, Sangro B, Marti-Climent J, Ruiz $\mathrm{M}$ et al. Positron emission tomography imaging of adenoviral-mediated transgene expression in liver cancer patients. Gastroenterology 2005; 128: 1787-1795.

14. Dempsey MF, Wyper D, Owens J, Pimlott S, Papanastassiou V, Patterson J et al. Assessment of ${ }^{123}$ I-FIAU imaging of herpes simplex viral gene expression in the treatment of glioma. Nucl Med Commun 2006; 27: 611-617.

15. Jacobs A, Voges J, Reszka R, Lercher M, Grossmann A, Kracht L et al. Positron-emission tomography of vector-mediated gene expression in gene therapy for gliomas. Lancet 2001; 358: 727-729.

16. Barton KN, Stricker H, Brown SL, Elshaikh M, Aref I, Lu M et al. Phase I study of noninvasive imaging of adenovirus-mediated gene expression in the human prostate. Mol Ther 2008; 16: 1761-1769.

17. Yaghoubi SS, Barrio JR, Dahlbom $M$, Iyer $M$, Namavari $M$, Satyamurthy $\mathrm{N}$ et al. Human pharmacokinetic and dosimetry studies of $\left[{ }^{18} \mathrm{~F}\right] \mathrm{FHBG}$ : A reporter probe for imaging herpes simplex virus type- 1 thymidine kinase reporter gene expression. J Nucl Med 2001; 42: 1225-1234.

18. Gambhir SS, Bauer E, Black ME, Liang Q, Kokoris MS, Barrio JR et al. A mutant herpes simplex virus type 1 thymidine kinase reporter gene shows improved sensitivity for imaging reporter gene expression with positron emission tomography. PNAS 2000; 97: 2785-2790.

19. Likar Y, Dobrenkov K, Olszewska M, Shenker L, Cai S, Hricak $\mathrm{H}$ et al. PET imaging of HSV1-tk mutants with acquired specificity toward pyrimidine- and acycloguanosine-based radiotracers. Eur J Nucl Med Mol Imaging 2009; 36: 1273-1282.

20. Likar Y, Dobrenkov K, Olszewska M, Vider E, Shenker L, Cai S et al. A new acycloguanosine-specific supermutant of herpes simplex virus type 1 thymidine kinase suitable for PET imaging and suicide gene therapy for potential use in patients treated with pyrimidine-based cytotoxic drugs. J Nucl Med 2008; 49: 713-720.

21. Hsieh C, Chen F, Wang H, Hwang J, Chang C, Lee $\mathrm{Y}$ et al. Generation of destabilized herpes simplex virus type 1 thymidine kinase as transcription reporter for PET reporter systems in molecular-genetic imaging. J Nucl Med 2008; 49: 142-150.

22. Hsieh C, Liu R, Wang H, Hwang J, Deng W, Chen J et al. In vitro evaluation of herpes simplex virus type 1 thymidine kinase reporter system in dynamic studies of transcriptional gene regulation. Nucl Med Biol 2006 Jul;33(5):653-60.

23. Najjar AM, Nishii R, Maxwell DS, Volgin A, Mukhopadhyay U, Bornmann WG et al. Molecular-genetic PET imaging using an HSV1-tk mutant reporter gene with enhanced specificity to acycloguanosine nucleoside analogs. J Nucl Med 2009; 50: 409-416.

24. Pantuck AJ, Berger F, Zisman A, Nguyen D, Tso CL, Matherly J et al. CL1-SR39: A noninvasive molecular imaging model of prostate cancer suicide gene therapy using positron emission tomography. J Urol 2002; 168: 1193-1198.

25. Pantuck AJ, Matherly J, Zisman A, Nguyen D, Berger F, Gambhir SS et al. Optimizing prostate cancer suicide gene therapy using herpes simplex virus thymidine kinase active site variants. Hum Gene Ther 2002; 13: 777-789.

26. Iyer $M$, Barrio JR, Namavari $M$, Bauer E, Satyamurthy $N$, Nguyen K et al. 8-[18F]Fluoropenciclovir: An improved reporter probe for imaging HSV1-tk reporter gene expression in vivo using PET. J Nucl Med 2001; 42: 96-105.
27. Min J, Iyer M, Gambhir SS. Comparison of $\left[{ }^{[8} \mathrm{F}\right] \mathrm{FHBG}$ and $\left[{ }^{14} \mathrm{C}\right]$ FIAU for imaging of HSV1-tk reporter gene expression: adenoviral infection vs stable transfection. Eur J Nucl Med Mol Imaging 2003; 30: 1547-1560.

28. Alauddin MA, Shahinian A, Gordon EM, Bading JR, Conti PS. Preclinical evaluation of the penciclovir analog 9-(4-[18F]fluoro-3-hydroxymethylbutyl)guanine for in vivo measurement of suicide gene expression with PET. J Nucl Med 2001; 42: 1682-1690.

29. Alauddin MA, Shahinian A, Gordon EM, Conti PS. Direct comparison of radiolabeled probes FMAU, FHBG, and FHPG as PET imaging agents for HSV1-tk expression in human breast cancer model. Mol Imaging 2004; 3: 76-84.

30. Alauddin MM, Conti PS. Synthesis and preliminary evaluation of 9-(4-[18F]-Fluoro-3-Hydroxymethylbutyl)Guanine ( $\left.\left[{ }^{18} \mathrm{~F}\right] \mathrm{FHBG}\right)$ : A new potential imaging agent for viral infection and gene therapy using PET. Nucl Med Biol 1998; 25: 175-180.

31. Chin FT, Namavari M, Levi J, Subbarayan M, Ray P, chen X et al. Semiautomated radiosynthesis and biological evaluation of [18F]FEAU: A novel PET imaging agent for HSV1-tk/sr39tk reporter gene expression. Mol Imaging Biol 2008; 10: 82-91.

32. Tjuvajev JG, Doubrovin M, Akhurst T, Cai S, Balatoni J, Alauddin MA et al. Comparison of radiolabeled nucleoside probes (FIAU, FHBG, and FHPG) for PET imaging of HSV1-tk gene expression. J Nucl Med 2002; 43: 1072-1083.

33. Johayem A, Raic-Malic S, Lazzati K, Schubiger PA, Scapozza L, Ametamey SM. Synthesis and characterization of a C(6) nucleoside analogue for the in vivo imaging of the gene expression of Herpes Simplex virus type- 1 thymidine kinase. Chemistry and Biodiversity 2006; 3: 274-282.

34. Yaghoubi SS, Couto MA, Chen C, Polavaram L, Cui G, Sen L et al. Preclinical safety evaluation of ${ }^{18} \mathrm{~F}-\mathrm{FHBG}$ : A PET reporter probe for imaging Herpes Simplex virus type 1 thymidine kinase (HSV1-tk) or mutant HSV1-sr39tk's expression. J Nucl Med 2006; 47: 706-715.

35. Yaghoubi SS, Gambhir SS. PET imaging of herpes simplex virus type 1 thymidine kinase (HSV1-tk) or mutant HSV1-sr39tk reporter gene expression in mice and humans using [ $\left.{ }^{18} \mathrm{~F}\right] \mathrm{FHBG}$. Nat Protoc 2007; 1: 3069-3075.

36. Yaghoubi SS, Barrio JR, Namavari M, Satyamurthy N, Phelps ME, Herschman HR et al. Imaging progress of herpes simplex virus type 1 thymidine kinase suicide gene therapy in living subjects with positron emission tomography. Cancer Gene Ther 2005; 12: 329-339.

37. Berger C, Flowers ME, Warren EH, Riddell SR. Analysis of transgene-specific immune responses that limit the in vivo persistence of adoptively transferred HSV-TK-modified donor T cells after allogeneic hematopoietic cell transplantation. Blood 2006; 107: 2294-2302.

38. Traversari C, Marktel S, Magnani Z, Mangia P, Russo V, Ciceri $\mathrm{F}$ et al. The potential immunogenicity of the TK suicide gene does not prevent full clinical benefit associated with the use of TK-transduced donor lymphocytes in HSCT for hematologic malignancies. Blood 2007; 109: 4708-4715.

39. Chitneni SK, Deroose CM, Balzarini J, Gijsbers R, Celen SJL, de Groot TJ et al. Synthesis and preliminary evaluation of ${ }^{18} \mathrm{~F}-$ or ${ }^{11} \mathrm{C}$-labeled bicyclic nucleoside analogues as potential probes for imaging Varicella-Zoster virus thymidine kinase gene expression using positron emission tomography. J Med Chem 2007; 50: 1041-1049.

40. Celen S, Cleynhens J, Deroose C, De Groot T, Ibrahimi A, Gijsbers $\mathrm{R}$ et al. Synthesis and biological evaluation of ${ }^{11} \mathrm{C}$-labeled Beta-galactosyl triazoles as potential PET tracers for in vivo LacZ reporter gene imaging. Bioorg Med Chem Lett 2009; 17: 5117-5125. 
41. Ghim CM, Lee SK, Takayama S, Mitchell RJ. The art of reporter proteins in science: past, present and future applications. BMB Reports 2010; 43: 451-460.

42. Gilad AA, Winnard Jr PT, Van Zijl PCM, Bulte JWM. Developing MR reporter genes: promises and pitfalls. NMR Biomed 2007; 20: 275-290.

43. Louie AY, Huber MM, Ahrens ET, Rothbacher U, Moats R, Jacobs RE et al. In vivo visualization of gene expression using magnetic resonance imaging. Nat Biotechnol 2000; 18: 321-325.

44. Serganova I, Ponomarev V, Blasberg R. Human reporter genes: potential use in clinical studies. Nucl Med Biol 2007; 34: 791-807.

45. MacLaren DC, Gambhir SS, Satyamurthy N, Barrio JR, Sharfstein S, Toyokuni T et al. Repetitive, non-invasive imaging of the dopamine D2 receptor as a reporter gene in living animals. Gene Ther 1999; 6: 785-791.

46. Hwang DW, Kang JH, Chang YS, Jeong JM, Chung J, Lee MC et al. Development of a dual membrane protein reporter system using sodium iodide symporter and mutant dopamine $\mathrm{D}_{2}$ receptor transgenes. J Nucl Med 2007; 48: 588-595.

47. Liang Q, Satyamurthy N, Barrio JR, Toyokuni T, Phelps ME, Gambhir SS et al. Noninvasive, quantitative imaging in living animals of a mutant dopamine D2 receptor reporter gene in which ligand binding is uncoupled from signal transduction. Gene Ther 2001; 8: 1490-1498.

48. Satyamurthy N, Barrio J, Bida G, Huang S, Mazziotta J, Phelps M. 3-(2'-[18F]fluoroethyl)Spiperone, a potent dopamine antagonist: synthesis, structural analysis and in vivo utilization in human. Appl Radiat Isotopes 1990; 41: 113-129.

49. Furukawa T, Lohith TG, Takamatsu S, Mori T, Tanaka T, Fujibayashi Y. Potential of the FES-hERL PET reporter gene system - Basic evaluation for gene therapy monitoring. Nucl Med Biol 2006; 33: 145-151.

50. Lohith TG, Furukawa T, Mori T, Kobayashi M, Fujibayashi Y. Basic evaluation of FES-hERL PET tracer-reporter gene system for in vivo monitoring of adenoviral-mediated gene therapy. Mol Imaging Biol 2008; 10: 245-252.

51. Chaudhuri TR, Rogers BE, Buchsbaum DJ, Mountz JM, Zinn KR. A noninvasive reporter system to image adenoviral-mediated gene transfer to ovarian cancer xenografts. Gynecol Oncol 2001; 83: 432-438.

52. Zinn KR, Buchsbaum DJ, chaudhuri TR, Mountz JM, Grizzle WE, Rogers BE. Noninvasive monitoring of gene transfer using a reporter receptor imaged with a high-affinity peptide radiolabeled with ${ }^{99 \mathrm{mTC}}$ or ${ }^{188} \mathrm{Re}$. J Nucl Med 2000; 41: 887-895.

53. Zinn KR, chaudhuri TR, Buchsbaum DJ, Mountz JM, Rogers BE. Detection and measurement of in vitro gene transfer by gamma camera imaging. Gene Ther 2001; 8: 291-299.

54. Rogers BE, chaudhuri TR, Reynolds PN, Manna DD, Zinn KR. Non-invasive gamma camera imaging of gene transfer using an adenoviral vector encoding an epitope-tagged receptor as a reporter. Gene Ther 2003; 10: 105-114.

55. Kenanova V, Barat B, Olafsen T, chatziioannou A, Herschman $\mathrm{HR}$, Braun J et al. Recombinant carcinoembryonic antigen as a reporter gene for molecular imaging. Eur J Nucl Med Mol Imaging 2009; 36: 104-114.

56. Wei LH, Olafsen T, Radu CG, Hildebrandt IJ, McCoy MR, Phelps ME et al. Engineered antibody fragments with infinite affinity as reporter genes for PET imaging. J Nucl Med 2008; 49: 1828-1835.

57. Kang HJ, Chung J, Lee YJ, Kim K, Jeong JM, Lee DS et al. Evaluation of transcriptional activity of the oestrogen receptor with sodium iodide symporter as an imaging reporter gene. Nucl Med Commun 2006; 27: 773-777.

58. Cho J-Y. A transporter gene (sodium iodide symporter) for dual purposes in gene therapy: Imaging and therapy. Curr Gene Ther 2002; 2: 393-402.
59. Cho J-Y, Shen DHY, Yang W, Williams B, Buckwalter TLF, La Perle KMD et al. In vivo imaging and radioiodine therapy following sodium iodide symporter gene transfer in animal model of intracerebral gliomas. Gene Ther 2002; 9: 1139-1145.

60. Chung J. Sodium iodide symporter: Its role in nuclear medicine. J Nucl Med 2002; 43: 1188-1200.

61. Goel A, Carlson SK, Classic KL, Greiner S, Naik S, Power AT et al. Radioiodide imaging and radiovirotherapy of multiple myeloma using VSV(delta51)-NIS, an attenuated vesicular stomatitis virus encoding the sodium iodide symporter gene. Blood 2007; 110: 2342-2350.

62. Moroz MA, Serganova I, Zanzonico P, Ageyeva L, Beresten T, Dyomina E et al. Imaging hNET reporter gene expression with 124I-MIBG. J Nucl Med 2007; 48: 827-836.

63. Ponomarev V, Doubrovin M, Shavrin A, Serganova I, Beresten $\mathrm{T}$, Ageyeva L et al. A human-derived reporter gene for noninvasive imaging in humans: mitochondrial thymidine kinase type 2. J Nucl Med 2007; 48: 819-826.

64. Campbell DO, Yaghoubi SS, Su Y, Lee JT, Auerbach MS, Herschman $\mathrm{H}$. et al. Structure-guided engineering of human thymidine kinase 2 as a positron emission tomography reporter gene for enhanced phosphorylation of a non-natural thymidine analog reporter probe. J Biol Chem. 2012;287:446-54.

65. Likar Y, Zurita J, Dobrenkov K, Shenker L, Cai S, Neschadim A et al. A new pyrimidine-specific reporter gene: a mutated human deoxycytidine kinase suitable for PET during treatment with acycloguanosine-based cytotoxic drugs. J Nucl Med 2010; 51: 1395-1403.

66. Chuang KH, Wang HE, Cheng TC, Tzou SC, Tseng WL, Hung WC et al. Development of a universal anti-polyethylene glycol reporter gene for noninvasive imaging of PEGylated probes. J Nucl Med 2010; 51: 933-941.

67. Lendvai G, Estrada S, Bergstrom M. Radiolabelled oligonucleotides for imaging of gene expression with PET. Curr Med Chem 2009; 16: 4445-4461.

68. Deng W, Yang WK, Lai W, Liu R, Hwang J, Yang D et al. Non-invasive in vivo imaging with radiolabelled FIAU for monitoring cancer gene therapy using herpes simplex virus type 1 thymidine kinase and ganciclovir. Eur J Nucl Med Mol Imaging 2004; 31: 99-109.

69. Haberkorn U, Altmann A, Morr I, Germann C, Oberdorfer F, Van Kaick G. Multitracer studies during gene therapy of hepatoma cells with Herpes Simplex Virus Thymidine Kinase and Ganciclovir. J Nucl Med 1997; 38: 1048-1054.

70. Kuruppu D, Brownell AL, Zhu A, Yu M, Wang X, Kulu Y et al. Positron emission tomography of herpes simplex virus 1 oncolysis. Cancer Res 2007; 67: 3295-3300.

71. Lanuti M, Gao G, Force SD, Chang MY, El Kouri C, Amin KM et al. Evaluation of an $\mathrm{E}_{1} \mathrm{E}_{4}$-Deleted adenovirus expressing the herpes simplex thymidine kinase suicide gene in cancer gene therapy. Hum Gene Ther 1999; 10: 463-475.

72. Yaghoubi S. Imaging reporter transgene expression in living subjects using positron emission tomography. Los Angeles: University of California, Los Angeles. 2002.

73. Yaghoubi SS, Wu L, Liang Q, Toyokuni T, Barrio JR, Namavari $\mathrm{M}$ et al. Direct correlation between positron emission tomographic images of two reporter genes delivered by two distinct adenoviral vectors. Gene Ther 2001; 8: 1072-1080.

74. Yaghoubi SS, Gambhir SS. Monitoring p53 therapeutic transgene expression in mice by imaging the expression of a linked HSV1-sr39tk PET reporter transgene. J Nucl Med 2003; 44: 30P [Abstract\#95].

75. Yu Y, Annala AJ, Barrio JR, Toyokuni T, Satyamurthy N, Namavari $\mathrm{M}$ et al. Quantification of target gene expression by imaging reporter gene expression in living animals. Nat Med 2000; 6: 933-937. 
76. Anton M, Wittermann C, Haubner R, Simoes M, Reder S, Essien $\mathrm{B}$ et al. Coexpression of herpesviral thymidine kinase reporter gene and VEGF gene for noninvasive monitoring of therapeutic gene transfer: an in vitro evaluation. J Nucl Med 2004; 45: 1743-1746.

77. Chen IY, Gheysens O, Ray S, Wang Q, Padmanabhan P, Paulmurugan $\mathrm{R}$ et al. Indirect imaging of cardiac-specific transgene expression using a bidirectional two-step transcriptional amplification strategy. Gene Ther 2010.

78. Chen IY, Wu JC, Min J, Sundaresan G, Lewis X, Liang Q et al. Micro-positron emission tomography imaging of cardiac gene expression in rats using bicistronic adenoviral vector-mediated gene delivery. Circulation 2004; 109: 1415-1420.

79. Wang Y, Iyer M, Annala AJ, Chappell S, Mauro V, Gambhir SS. Noninvasive monitoring of target gene expression by imaging reporter gene expression in living animals using improved bicistronic vectors. J Nucl Med 2005; 46: 667-674.

80. Sun X, Annala AJ, Yaghoubi SS, Barrio JR, Nguyen KN, Toyokuni $\mathrm{T}$ et al. Quantitative imaging of gene induction in living animals. Gene Ther 2001; 8: 1572-1579.

81. Wang Y, Iyer M, Annala A, Wu L, Carey M, Gambhir SS. Noninvasive indirect imaging of vascular endothelial growth factor gene expression using bioluminescence imaging in living transgenic mice. Physiol Genomics 2006; 24: 173-180.

82. Ray P, Wu AM, Gambhir SS. Optical bioluminescence and positron emission tomography imaging of a novel fusion reporter gene in tumor xenografts of living mice. Cancer Res 2003; 63: 1160-1165.

83. Ray P, De A, Min J, Tsien RY, Gambhir SS. Imaging tri-fusion multimodality reporter gene expression in living subjects. Cancer Res 2004; 64: 1323-1330.

84. Ray P, Gambhir SS. Multimodality imaging of reporter genes. In: Yaghoubi SS, Gambhir SS, eds. Molecular Imaging With Reporter Genes. Cambridge University Press. 2010: 113-126.

85. Ray P, Tsien R, Gambhir SS. Construction and validation of improved triple fusion reporter gene vectors for molecular imaging of living subjects. Cancer Res 2007; 67: 3085-3093.

86. Kesarwala AH, Prior JL, Sun J, Harpstrite SE, Sharma V, Piwnica-Worms D. Second-generation triple reporter for bioluminescence, micro-positron emission tomography, and fluorescence imaging. Mol Imaging 2006; 5: 465-474.

87. Jacobs A, Dubrovin M, Hewett J, Sena-Esteves M, Tan CW, Slack $\mathrm{M}$ et al. Functional coexpression of HSV-1 thymidine kinase and green fluorescent protein: implications for noninvasive imaging of transgene expression. Neoplasia 1999; 1: 154-161.

88. Ponomarev V, Doubrovin M, Serganova I, Vider J, Shavrin A, Beresten $\mathrm{T}$ et al. A novel triple-modality reporter gene for whole-body fluorescent, bioluminescent, and nuclear noninvasive imaging. Eur J Nucl Med Mol Imaging 2004; 31: 740-751.

89. Wu JC, chen IY, Wang Y, Tseng JR, Chhabra A, Salek M et al. Molecular Imaging of the kinetics of vascular endothelial growth factor gene expression in ischemic myocardium. Circulation 2004; 110: 685-691.

90. Morstyn G, Sheridan W (eds). Cell therapy: stem cell transplantation, gene therapy, and cellular immunotherapy. Cambridge University Press: Cambridge, 1996.

91. Gupta R, Losordo DW. Challenges in the translation of cardiovascular cell therapy. J Nucl Med 2010; 51: 122S-127S.

92. Salem ML, Cole DJ. Dendritic cell recovery post-lymphodepletion: a potential mechanism for anti-cancer adoptive $T$ cell therapy and vaccination. Cancer Immunol Immunother 2010; 59: 341-353.

93. June $\mathrm{CH}$. Adoptive $\mathrm{T}$ cell therapy for cancer in the clinic. The Journal of Clinical Investigation 2007; 117: 1466-1476.

94. Olasz EB, Lang L, Seidel J, Green MV, Eckelman WC, Katz SI. Fluorine-18 labeled mouse bone marrow-derived dendritic cells can be detected in vivo by high resolution projection imaging. J Immunol Methods 2002; 260: 137-148.

95. Ahrens ET, Flores $\mathrm{R}, \mathrm{Xu} \mathrm{H}$, Morel PA. In vivo imaging platform for tracking immunotherapeutic cells. Nat Biotechnol 2005; 23: 983-987.

96. Kircher MF, Allport JR, Graves EE, Love V, Josephson L, Lichtman $\mathrm{AH}$ et al. In vivo high resolution three-dimensional imaging of antigen-specific cytotoxic T-lymphocyte trafficking to tumors. Cancer Res 2003; 63: 6838-6846.

97. Morse MA, Coleman RE, Akabani G, Niehaus N, Coleman D, Lyerly HK. Migration of human dendritic cells after injection in patients with metastatic malignancies. Cancer Res 1999; 59: 56-58.

98. Adonai N, Nguyen KN, Walsh J, Iyer M, Toyokuni T, Phelps $\mathrm{ME}$ et al. Ex vivo cell labeling with ${ }^{64} \mathrm{Cu}$-pyruvaldehyde-bis(N4-methylthiosemicarbazone) for imaging cell trafficking in mice with positron-emission tomography. PNAS 2002; 99: 3030-3035.

99. Verdijk P, Scheenen TWJ, Lesterhuis WJ, Gambarota G, Veltien AA, Walczak $P$ et al. Sensitivity of magnetic resonance imaging of dendritic cells for in vivo tracking of cellular cancer vaccines. Int J Cancer 2006; 120: 978-984.

100.Vuu K, Xie J, McDonald MA, Bernardo M, Hunter F, Zhang Y et al. Gadolinium-Rhodamine nanoparticles for cell labeling and tracking via magnetic resonance and optical imaging. Bioconjug Chem 2005; 16: 995-999.

101.Chung J, Kang JH, Kang KW. Reporter gene imaging with PET/SPECT. In: Gambhir SS, Yaghoubi SS, eds. Molecular Imaging With Reporter Genes. Cambridge University Press. 2010: 70-87.

102. Yaghoubi SS, Creusot RJ, Ray P, Fathman CG, Gambhir SS. Multimodality imaging of T-cell hybridoma trafficking in collagen-induced arthritic mice: image-based estimation of the number of cells accumulating in mouse paws. Journal of Biomedical Optics 2007; 12: 064025_064021-064011.

103.Waerzeggers Y, Klein M, Miletic H, Himmelreich U, Li H, Monfared $\mathrm{P}$ et al. Multimodal imaging of neural progenitor cell fate in rodents. Mol Imaging Biol 2008; 7: 77-91.

104.Cao F, Lin S, Xie X, Ray P, Patel M, Zhang X et al. In vivo visualization of embryonic stem cell survival, proliferation, and migration after cardiac delivery. Circulation 2006; 113: 1005-1014.

105.Wu JC, chen IY, Sundaresan G, Min J, De A, Qiao J et al. Molecular imaging of cardiac cell transplantation in living animals using optical bioluminescence and positron emission tomography. Circulation 2003; 108: 1302-1305.

106.Su H, Chang DS, Gambhir SS, Braun J. Monitoring the antitumor response of naive and memory CD8 T cells in RAG1\%mice by positron-emission tomography. J Immunol 2006; 176: 4459-4467.

107.Su H, Forbes A, Gambhir SS, Braun J. Quantitation of cell number by a positron emission tomography reporter gene strategy. Mol Imaging Biol 2004; 6: 139-148.

108.Kim S, Doudet DJ, Studenov AR, Nian C, Ruth TJ, Gambhir SS et al. Quantitative micro positron emission tomography (PET) imaging for the in vivo determination of pancreatic islet graft survival. Nat Med 2006; 12: 1423-1428.

109.Kim SJ, Doudet D, Ruth TJ, Gambhir SS, McIntosh CHS. Quantitative in vivo imaging of transplanted islets using micro positron emission tomography scanning. Nat Med 2006; 12: 1423-1428.

110.Kim YJ, Dubey P, Ray P, Gambhir SS, Witte ON. Multimodality imaging of lymphocytic migration using lentiviral-based transduction of a tri-fusion reporter gene. Mol Imaging Biol 2004; 6: 331-340. 
111.Lu Y, Dang H, Middleton B, Zhang Z, Washburn L, Stout DB et al. Noninvasive imaging of islet grafts using positron-emission tomography. PNAS 2006; 103: 11294-11299.

112.Dubey P, Su H, Adonai N, Du S, Rosato A, Braun J et al. Quantitative imaging of $\mathrm{T}$ cell antitumor response by positron-emission tomography. PNAS 2003; 100: 1232-1237.

113.Shu CJ, Guo S, Kim YJ, Shelly SM, Nijagal A, Ray P et al. Visualization of a primary anti-tumor immune response by positron emission tomography. PNAS 2005; 102: 17412-17417.

114.Shu CJ, Radu CG, Shelly SM, Vo DD, Prins R, Ribas A et al. Quantitative PET reporter gene imaging of CD8+ T cells specific for a melanoma-expressed self-antigen. Int Immunol 2009; 21: 155-165.

115.Cao F, Drukker M, Lin S, Sheikh A, Xie X, Li Z et al. Molecular imaging of embryonic stem cell misbehavior and suicide gene ablation. Cloning and Stem Cells 2007; 9: 107-117.

116.Dobrenkov K, Olszewska M, Likar Y, Shenker L, Gunset G, Cai $\mathrm{S}$ et al. Monitoring the efficacy of adoptively transferred prostate cancer-targeted human T lymphocytes with PET and bioluminescence imaging. J Nucl Med 2008; 49: 1162-1170.

117.Koehne G, Doubrovin M, Doubrovina E, Zanzonico P, Gallardo HF, Ivanova A et al. Serial in vivo imaging of the targeted migration of human HSV-TK-transduced antigen-specific lymphocytes. Nat Biotechnol 2003; 21: 405-413.

118.Lo W, Hsu C, Wu ATH, Yang L, Chen W, Chiu W et al. A novel cell-based therapy for contusion spinal cord injury using GDNF-delivering NIH3T3 cells with dual reporter genes monitored by molecular imaging. J Nucl Med 2008; 49: 1512-1519.

119.Doubrovin MM, Doubrovina E, Zanzonico P, Sadelain M, Larson SM, O'Reilly RJ. In vivo imaging and quantitation of adoptively transferred human antigen-specific $\mathrm{T}$ cells transduced to express a human norepinephrine transporter gene. Cancer Res 2007; 67: 11959-11969.

120.Dotti G, Tian M, Savoldo B, Najjar A, Cooper LJN, Jackson J et al. Repetitive noninvasive monitoring of HSV1-tk-expressing $\mathrm{T}$ cells intravenously infused into nonhuman primates using positron emission tomography and computed tomography with ${ }^{18}$ F-FEAU. Mol Imaging 2009; 8: 230-237.

121.Qiao H, Surti S, Choi SR, Raju K, Zhang H, Ponde DE et al. Death and Proliferation Time Course of Stem Cells Transplanted in the Myocardium. Mol Imaging Biol 2009; 11: 408-414.

122.Terrovitis J, Kwok KF, Lautamaki R, Engles JM, Barth AS, Kizana E et al. Ectopic expression of the sodium-iodide symporter enables imaging of transplanted cardiac stem cells in vivo by single-photon emission computed tomography or positron emission tomography. J Am Coll Cardiol 2008; 52: 1652-1660.

123.Willmann JK, Paulmurugan R, Rodriguez-Porcel M, Stein W, Brinton TJ, Connolly AJ et al. Imaging Gene Expression in $\mathrm{Hu}-$ man Mesenchymal Stem Cells: From Small to Large Animals. Radiology 2009; 252: 117-127. 